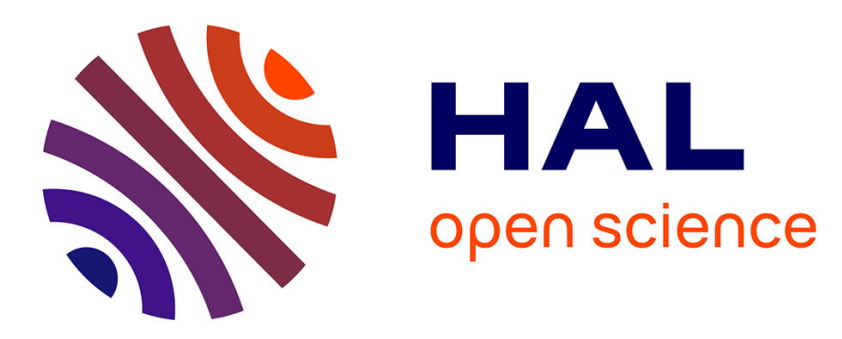

\title{
Steady erosion rates in the Himalayas through late Cenozoic climatic changes
}

Sébastien Lenard, Jerome Lave, Christian France-Lanord, Georges Aumaitre, Didier Bourlès, Karim Keddadouche

\section{- To cite this version:}

Sébastien Lenard, Jerome Lave, Christian France-Lanord, Georges Aumaitre, Didier Bourlès, et al.. Steady erosion rates in the Himalayas through late Cenozoic climatic changes. Nature Geoscience, 2020, 13 (6), pp.448-452. 10.1038/s41561-020-0585-2 . hal-03096681

\section{HAL Id: hal-03096681 https://hal.science/hal-03096681}

Submitted on 5 Jan 2021

HAL is a multi-disciplinary open access archive for the deposit and dissemination of scientific research documents, whether they are published or not. The documents may come from teaching and research institutions in France or abroad, or from public or private research centers.
L'archive ouverte pluridisciplinaire HAL, est destinée au dépôt et à la diffusion de documents scientifiques de niveau recherche, publiés ou non, émanant des établissements d'enseignement et de recherche français ou étrangers, des laboratoires publics ou privés. 
Accepted version of the manuscript entitled «Steady erosion rates in the Himalayas through late Cenozoic climatic changes » published in Nature Geoscience in june, 2020.

The main text and figures (p.2-17) is followed by a methodologic section (p.18-30), with Extended Data Figures (p.31-37), source data for figures (p.38-44) and Supplementary Information (p.45-46). The Pangea repository for the datasets generated and analysed is indicated p. 27.

Please cite as:

Lenard, S.J.P., Lavé, J., France-Lanord, C., Aumaître, G., Bourlès, D.L., Keddadouche, K., 2020. Steady erosion rates in the Himalayas through late Cenozoic climatic changes. Nature Geoscience 13, 448-452. https://doi.org/10.1038/s41561-020-0585-2 
Title: Manuscript of steady erosion rates in the Himalayas through late Cenozoic climatic changes

Authors: Sebastien J.P. Lenard ${ }^{1 *}$, Jérôme Lavé ${ }^{1}$, Christian France-Lanord ${ }^{1 * *}$, Georges Aumaître $^{2}$, Didier L. Bourlès ${ }^{2}$, Karim Keddadouche ${ }^{2}$

\section{Affiliations:}

${ }^{1}$ Université de Lorraine, CNRS, CRPG, F-54000 Nancy, France

${ }^{2}$ Université Aix-Marseille, CNRS-IRD-Collège de France, UM 34 CEREGE, Technopôle de l'Environnement Arbois-Méditerranée, BP80, 13545 Aix-en-Provence, France

*e-mail: sebastien.lenard@gmail.com

**e-mail: cfl@crpg.cnrs-nancy.fr 
Sediment accumulation rates and thermal trackers suggest a substantial and global increase in erosion rates over the last few million years. That increase is commonly associated with the impact of the Northern Hemisphere glaciation, but methodological biases have led researchers to debate this hypothesis. Here, we test whether Himalayan erosion rates increased by measuring beryllium $10\left({ }^{10} \mathrm{Be}\right)$ in the sediment of the Bengal Bay seabed. Sediment originated from rocks that produced ${ }^{10} \mathrm{Be}$ under the impact of cosmic rays during erosion near surface. Thus, the ${ }^{10} \mathrm{Be}$ concentrations tell erosion rates. The ${ }^{10} \mathrm{Be}$ concentration of the Bengal Bay sediment depends on the contributions of the Ganga and Brahmaputra Rivers. Their sediments have distinct ${ }^{10} \mathrm{Be}$ concentrations because of distinct elevations and erosion in their drainage basins. Variable contributions could thus complicate erosion rate calculation. We traced these contributions by a provenance study using the $\mathrm{Sr}$ and $\mathrm{Nd}$ isotopic sediment compositions. Within uncertainties of $\pm 30 \%$, our reconstructed past erosion rates show no long-term increase for the last six million years. This stability suggests that climatic changes during the late Cenozoic have an undetectable impact on the erosion patterns in the Himalayas, at least on the ten-thousand to million-year timescales accounted for by our dataset.

Climate forcing of erosion rates during the late Cenozoic has been suggested on the basis of a substantial increase in (1) sediment accumulation rates ${ }^{1-4}$ and (2) exhumation rates derived from in situ thermochronometry ${ }^{5}$. Such an increase has been attributed to the amplification of climate variability and repeated glaciations ${ }^{4,6}$. However, this hypothesis seems at odds with global proxies such as the seawater ${ }^{10} \mathrm{Be} /{ }^{9} \mathrm{Be}$ which indicates steady chemical weathering during the late Cenozoic ${ }^{7}$. Assuming that physical erosion and chemical weathering increase concurrently, this proxy suggests constant erosion rates ${ }^{7}$. An intense debate has ensued about the resolution and biases of the currently used approaches ${ }^{7-9}$. Validating the climate forcing hypothesis requires new independent approaches. Cosmogenic nuclides such as ${ }^{10} \mathrm{Be}$ in detrital sediment are common tracers for modern erosion rates ${ }^{10}$. More recently, they have been applied for paleoerosion rates ${ }^{11-14}$.

In this study, we quantify the paleoerosion rates of the Himalayas since the late Miocene (ca. $6 \mathrm{Ma}$ ) by the analysis of ${ }^{10} \mathrm{Be}$ accumulated in the terrigenous sediment of the Bengal Fan. Erosion rates in the Himalayas may have been impacted by climatic changes 
during the late Cenozoic. In this mountain range, fluctuations in ice cover vary from less than $5 \%$ today $^{15}$ to up to $20 \%$ during the Last Glacial Maximum ${ }^{16}$, and monsoonal precipitations increased in variability during the late Cenozoic ${ }^{17}$.

\section{Approach for erosion rate quantification}

The sediment eroded from the Central and Eastern Himalayas is conveyed by the Ganga and the Brahmaputra Rivers to the Bengal Delta and Shelf, where it is dispersed across the Bengal Fan through a $3,000 \mathrm{~km}$-long turbiditic system ${ }^{18,19}$ (Fig. 1). The International Ocean Discovery Program (IODP) Expeditions 353 and 354 drilled the Middle Bengal Fan at latitudes of $16^{\circ} \mathrm{N}$ and $8^{\circ} \mathrm{N}^{20,21}$. The sediment recovered by the Expeditions provides an unprecedented record of Himalayan erosion. As turbiditic channels migrate over time, individual sites of the Bengal Fan record a discontinuous terrigenous sedimentation ${ }^{22}$. To alleviate the gaps in local sedimentation and to study a record as complete as possible, we collected and analysed samples from four drill sites in the Bengal Fan. We complemented this record by the analysis of the modern sand of the Lower Meghna, presently located after the confluence of the Ganga and the Brahmaputra.

The turbiditic sediment includes sand-rich lobe deposits suitable for in situ ${ }^{10} \mathrm{Be}$ cosmogenic nuclide measurements ${ }^{23-25}$ in the fine-grained quartz fraction. The ${ }^{10} \mathrm{Be}$ concentrations were corrected for radioactive decay since deposition using the available age constraints ${ }^{20,21,26-29}$ to obtain ${ }^{10} \mathrm{Be}$ paleoconcentrations. During aerial sediment transfer, temporary storage induces additional ${ }^{10} \mathrm{Be}$ build-up in sediment. This contribution is limited to a $\sim 15 \%$ and $\sim 0 \%$ increase in the Ganga and Brahmaputra plains, respectively ${ }^{30,31}$ (i.e. within our analytical uncertainties), and was not accounted for. The resulting ${ }^{10} \mathrm{Be}$ paleoconcentrations were interpreted in terms of paleoerosion rates averaged throughout the Central and Eastern Himalayan Arc.

We conducted a complementary provenance study based on the $\mathrm{Sr}$ and $\mathrm{Nd}$ isotopic compositions $^{32}$ in the silicate fraction of the Bengal Fan samples. Using the distinct isotopic compositions of the modern sediment in the Ganga and Brahmaputra Rivers ${ }^{30,31,33-35}$, we 
Fig. 1. Map of the Himalayan region and location of study sites in the Middle Bengal Fan. Sites drilled by International Ocean Discovery Program (IODP) in turbidites of the Bengal Fan and sites of modern river sand were analysed. The Bengal Fan accumulates one to six $\mathrm{km}$ of past Himalayan sediment at the drill sites (sediment isopachs in grey ${ }^{49,50}$ ). Sediment originates from the Transhimalaya and the Himalaya sensu stricto (s.s., dashed black lines), which have distinct mean elevation and erosion rates ${ }^{30,31}$, and distinct isotopic signatures ${ }^{33-35}$. G: Ganga River at Harding Bridge, B: Brahmaputra River at Sirajganj/Jamuna Bridge, Bangladesh, BD: upstream Brahmaputra River at Dibrugarh, LM: Lower Meghna River, YT: Yarlung-Tsangpo River, S: Shillong Plateau.

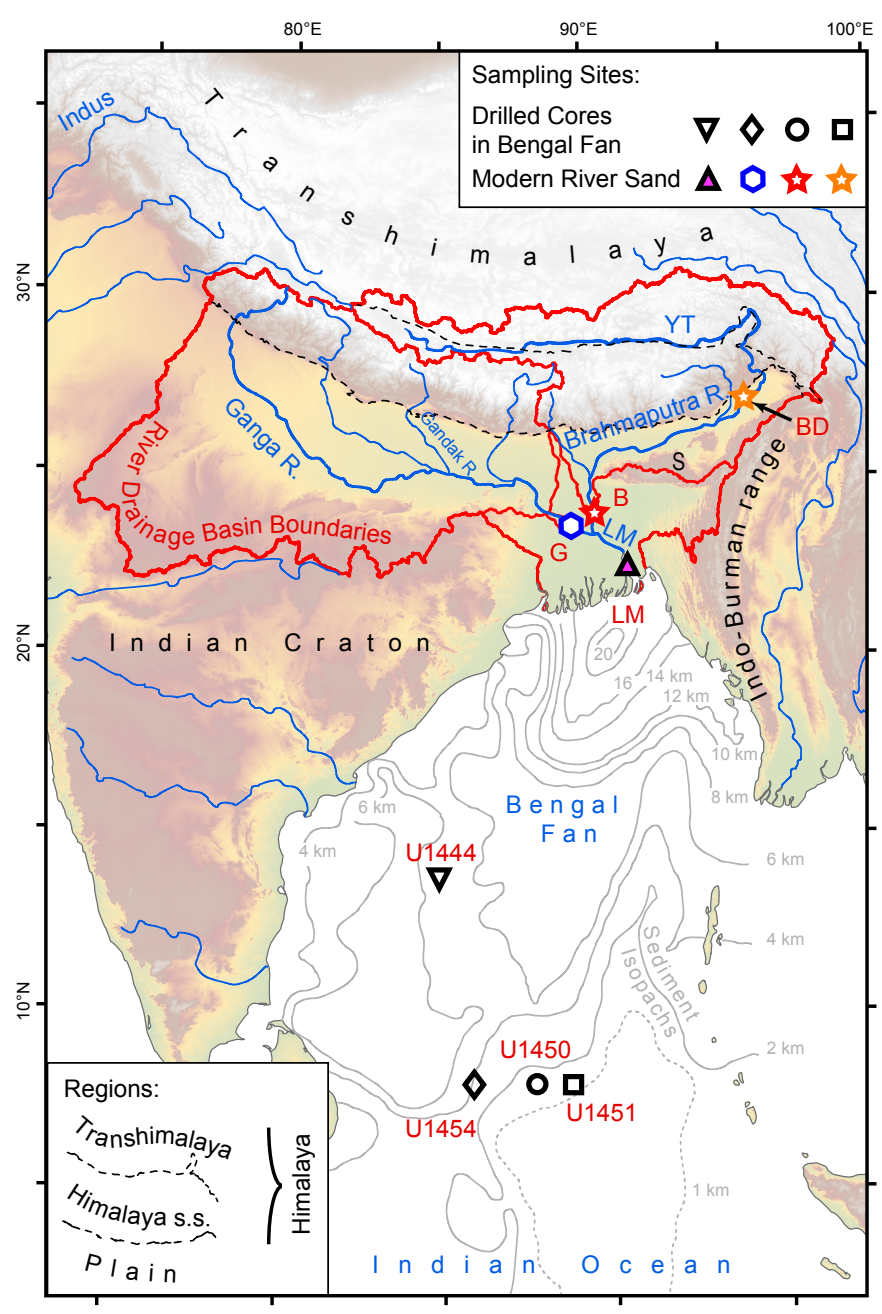


provide additional constraints on the relative contributions of the Central and Eastern Himalayas in the Bengal Fan sedimentary mix.

\section{${ }^{10} \mathrm{Be}$ concentrations and apparent erosion rates}

The ${ }^{10} \mathrm{Be}$ concentrations reflect erosion rates throughout the source basin of the Bengal Fan. They average the signal of several million grains of quartz eroded over $\sim 1 \mathrm{ka}$ on mountain hillslopes. During its transfer through the plain, the sediment may be temporarily and repeatedly stored and reworked ${ }^{36}$. These processes may damp the high-frequency content (periods of 1-10 ka) of the mountain-derived signal. Farther downstream, between the shelf and the distal fan, mixing during turbiditic transport may also smooth the signal. As these processes and the averaging time span of turbiditic mixing are not precisely documented, and because spacing of our samples is variable, we will focus our discussion on the long-term trend of erosion rates. They were averaged over intervals of 0.5 to $2.5 \mathrm{Ma}$, determined by the provenance study.

The ${ }^{10} \mathrm{Be}$ paleoconcentrations for the Bengal Fan average $31 \pm 12 \times 10^{3}$ atom $/ \mathrm{g}(1$ sigma uncertainty) over the last $6.2 \mathrm{Ma}$, with fluctuations between $12 \times 10^{3}$ and $64 \times 10^{3}$ atom $/ \mathrm{g}$ (Fig. 2a,b, Extended Data Fig. 1). With an average ${ }^{10}$ Be concentration of $38 \pm 8 \times 10^{3}$ atom $/ \mathrm{g}$, the modern sand of the Lower Meghna yields results similar in the error bars to those of the Bengal Fan samples. Between ca. 4.5 and 6.2 Ma (2 values) and between 0.07 and $1.8 \mathrm{Ma}$ (17 values), the paleoconcentrations are close to the average value of $31 \pm 12 \times 10^{3}$ atom $/ \mathrm{g}$, and the dispersion is smaller than that observed for the modern sand of the Brahmaputra ${ }^{31}$ and the Lower Meghna (Fig. 2b). In contrast, the 1.8-4.5 Ma period (7 values) shows a larger variability, potentially by a factor of two or three. But exploring this variability would require further measurements and lower uncertainties for the lowest concentrations/highest erosion rates (Methods). Despite variations in dispersion, the ${ }^{10} \mathrm{Be}$ signal averaged over intervals of 0.5 to $2.5 \mathrm{Ma}$ has been steady since $6.2 \mathrm{Ma}$. 

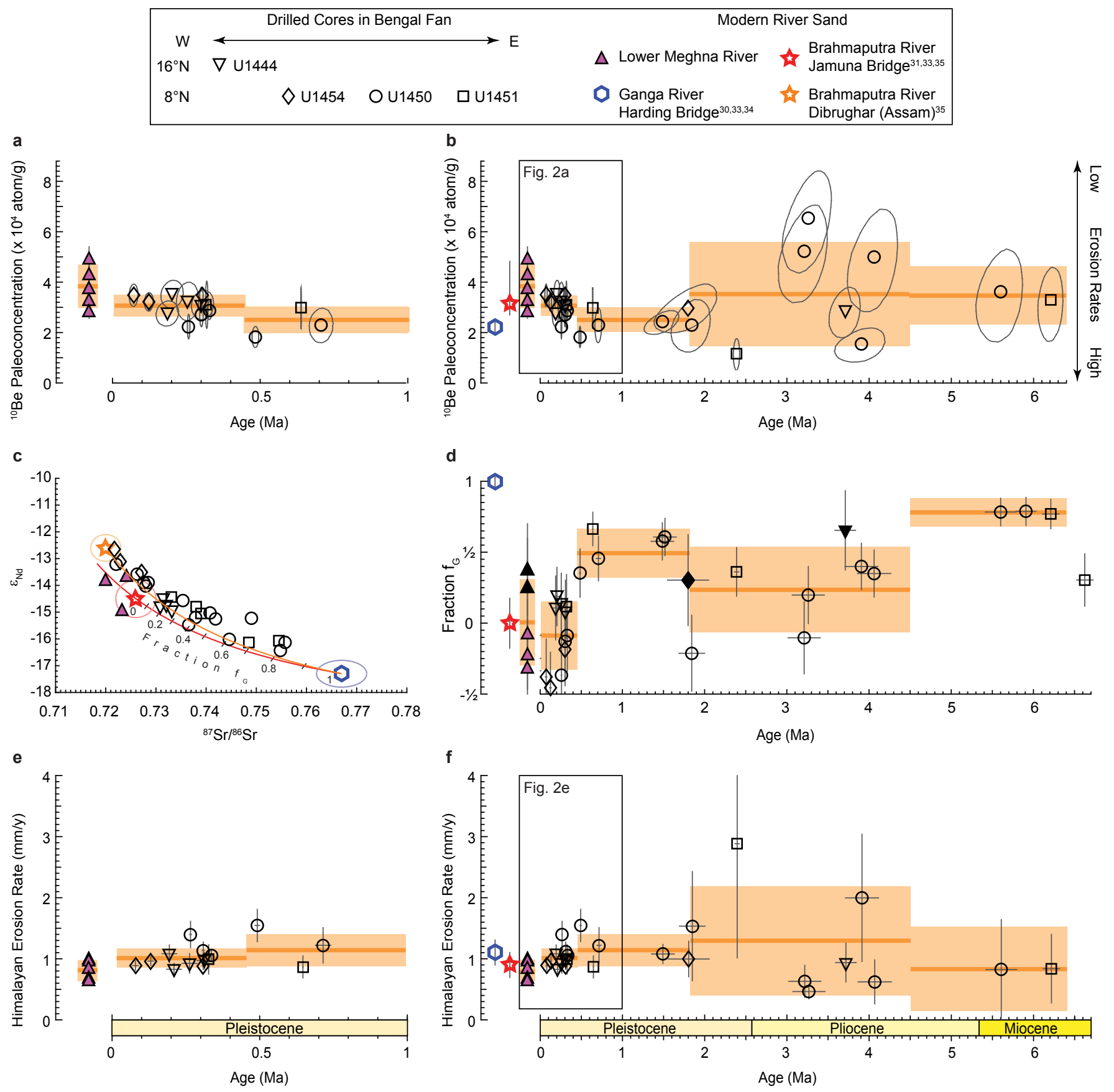

Intense, 100-ky Glacial Cycles 


\section{Fig. 2. New ${ }^{10} \mathrm{Be}$ and $\mathrm{Sr}-\mathrm{Nd}$ isotopic constraints on late Cenozoic Himalayan erosion rates from the Bengal Fan and Lower Meghna River.}

Evolution of ${ }^{10} \mathrm{Be}$ paleoconcentrations (a,b), Sr-Nd isotopic compositions (c), derived fraction $f_{G}$ of the Bengal Fan and Lower Meghna River sand issued from the Ganga Basin (d), and calculated Himalayan erosion rates $(\mathbf{e}, \mathbf{f})$. The ${ }^{10} \mathrm{Be}$ signal integrates erosion over $\sim 1 \mathrm{ka}$ and is damped during plain transfer over $\sim 1-10 \mathrm{ka}$ (concentrations inversely correlated to erosion rates). The 1- $\sigma$ uncertainty (ellipses or error bars in grey) mainly derives from the ${ }^{10} \mathrm{Be}$ analytical measurements and from dating uncertainties for a few samples (a,b,e,f), and from the uncertainties of the Ganga and Brahmaputra Rivers isotopic signatures (d). Published data from the Ganga and Brahmaputra Rivers are indicated for comparison ${ }^{30,31,33-35}$. Orange lines and boxes represent the average and 1- $\sigma$ standard deviations computed over intervals with homogeneous Sr-Nd isotopic composition. The influence of the selected intervals on the average values remains limited (Extended Data Fig. 6). The two curves in (c) show the mixing hyperbolas between the Ganga and the Brahmaputra Rivers in red and between the Ganga River and the Brahmaputra River at Dibrugarh, Assam (BD, Fig. 1) in orange ${ }^{33-35}$. For samples without $\mathrm{Sr}-\mathrm{Nd}$ isotopic measurements, we computed $\mathrm{f}_{\mathrm{G}}$ from the $\mathrm{Sr}$ concentration (black-filled symbols in d, Extended Data Fig. 3). Three samples measured for Sr-Nd isotopes were not measured for ${ }^{10} \mathrm{Be}$ concentrations. The erosion rates were determined on the Himalayan s.s. and the Transhimalayan parts of the basin, under the assumption of regional climate forcing of erosion rates. 
The apparent mean Himalayan erosion rate $e$ is derived from our ${ }^{10} \mathrm{Be}$ paleoconcentrations $C$ using the classical equation ${ }^{10}$ (Methods):

$e=\frac{\Lambda}{\rho} \frac{P}{C}(1)$

with $P$ the mean production rate of the modern Himalayan part of the basin (Fig. 1), $\Lambda$ the nucleon attenuation length and $\rho$ the crustal rock density. The paleoerosion rates (Dataset in the Pangaea Repository) are similar on average to the modern value of $\sim 1 \mathrm{~mm} / \mathrm{y}$ derived from the concentrations of the Ganga and Brahmaputra ${ }^{30,31}$. They do not display a long-term increasing trend.

Equation (1) applied for paleoerosion is valid given four conditions (Methods). (I) The Earth magnetic dipole variations should have had a limited impact on the cosmogenic nuclide production rate (Extended Data Fig. 2), within the range of uncertainties of the ${ }^{10} \mathrm{Be}$ concentrations. (II) The extent and elevation of the basins of the Ganga and Brahmaputra should have remained stable. (III) Temporary sequestration in the floodplain should have had a negligible impact on the ${ }^{10} \mathrm{Be}$ concentrations. (IV) Each location in the Ganga and Brahmaputra basins should have contributed to the sediment deposited in the Bengal Fan Sites and in the Lower Meghna. Condition (IV) is further examined with our provenance analyses.

\section{Sr-Nd isotopes and test of the climate forcing hypothesis}

The ${ }^{87} \mathrm{Sr} /{ }^{86} \mathrm{Sr}$ and $\varepsilon_{\mathrm{Nd}}$ values for the Bengal Fan and the Lower Meghna covary along a mixing hyperbola from 0.721 to 0.756 and from -12.6 to -16.2 , respectively, within 2- $\sigma$ errors of $0.005{ }^{87} \mathrm{Sr} /{ }^{86} \mathrm{Sr}$ and $1 \varepsilon_{\mathrm{Nd}}$ (Fig. 2c, Supplementary Information). The endmember with low $\varepsilon_{\mathrm{Nd}}$ and high ${ }^{87} \mathrm{Sr} /{ }^{86} \mathrm{Sr}$ tends towards the composition of the Ganga in Bangladesh ${ }^{33,34}$ and corresponds to the erosion of Himalayan rock formations sensu stricto (Himalaya s.s., Fig. 1): the Lesser Himalaya, the High Himalaya Crystalline and the Tethyan Sedimentary Series. The endmember with high $\varepsilon_{\mathrm{Nd}}$ and low ${ }^{87} \mathrm{Sr} /{ }^{86} \mathrm{Sr}$ overlaps the composition of the Brahmaputra in Bangladesh ${ }^{33,35}$ and reaches the composition of the Brahmaputra sampled in Assam close to the mountain range outlet ${ }^{35}$ (orange star on Fig. 2c). The composition of the 
Brahmaputra sediment reflects a mixing between the Himalaya s.s., the Gangdese Belt (Transhimalaya) and the mantle-derived formations drained by the Yarlung-Tsangpo and the eastern tributaries of the Brahmaputra ${ }^{35}$.

The contribution of the Ganga sand to the Bengal Fan and Lower Meghna sands, defined as $f_{G}$, is derived from our isotopic ratios $R$, i.e. ${ }^{87} \mathrm{Sr} /{ }^{86} \mathrm{Sr}$ and $\varepsilon_{\mathrm{Nd}}$, using:

$f_{G}=\frac{\left(R-R_{B}\right) \times C_{B}}{C_{G} \times\left(R_{G}-R\right)+\left(R-R_{B}\right) \times C_{B}}$

with $C_{G}, R_{G}$ and $C_{B}, R_{B}$ the elemental concentrations and isotopic ratios of the Ganga and the Brahmaputra, respectively. Our isotopic ratios correspond to $f_{G}$ which ranges from $75 \%$ to $40 \%$ and which displays a clear decrease since $0.45 \mathrm{Ma}$, irrespective of the drill Site position (Fig. 2d, Supplementary Information).

Assuming that Condition (IV) is verified, i.e. each location in the Ganga and the Brahmaputra basins contribute to the sediment deposits, $f_{G}$ is expected to reflect relative changes in erosion rates between the Ganga and Brahmaputra basins. Nevertheless, $f_{G}$ is close to $0 \%$ for the modern Lower Meghna (Fig. 2d). This low contribution of the Ganga is confirmed by the Sr concentration of the bulk sediment (Extended Data Fig. 3b) showing that the sandy bedload composition of the Lower Meghna overlaps with the composition of the Brahmaputra sediment. Such a reduced value of $f_{G}$ seems at odds with an expected value of $\sim 35 \%$ calculated from the ${ }^{10}$ Be-derived erosive fluxes ${ }^{30,31}$. But our geochemical and granulometric budgets (Extended Data Fig. 4) indicate that $\sim 60 \%$ of the Ganga sand may be sequestered in the Ganga floodplain, which suggests that the Ganga contribution to the Lower Meghna sand is less than $\sim 18 \%$. Our results imply a sharp difference in sand sequestration and export between the Ganga and the Brahmaputra floodplains in modern times.

For the Bengal Fan samples, the large variations of $f_{G}$ could similarly reflect changes in sand sequestration in the floodplains of both rivers. Alternatively, they could reflect changes in sediment routing. Distinct delta outlets and turbiditic channels for the Ganga and Brahmaputra ${ }^{18,27,37}$ may have led to pure Brahmaputra or Ganga signatures in the turbiditic record. 
Considering that a significant part of the erosion products from the Ganga Basin is absent from the samples younger than $0.45 \mathrm{Ma}$, equation (1) is invalid for these samples and the mean Himalayan erosion rate remains undetermined. To take into account the impact of the variable export on the ${ }^{10} \mathrm{Be}$ paleoconcentrations (Extended Data Fig. 5) and calculated erosion rates, and to further explore the trend of erosion rates, we use the climate forcing scenario developed below (detailed computation in Methods).

The mixing of two endmembers with ${ }^{10} \mathrm{Be}$ concentrations $C_{G}$ and $C_{B}$ yields a final concentration $C$ that is a function of $f_{G}$ (the indices $G$ and $B$ indicating the Ganga and Brahmaputra, respectively):

$C=f_{G} \times C_{G}+\left(1-f_{G}\right) \times C_{B}(2)$

At steady state, according to equation (1), $C_{G}$ and $C_{B}$ depend on the unknown mean erosion rates $e_{G}$ and $e_{B}$ of each drainage basin.

Under the simplifying assumption that most Himalayan landscapes respond similarly to global climate forcing, $e_{G}$ and $e_{B}$ would co-vary over time as a function of $K(t)$, a regional climatic amplification factor of erosion relative to modern conditions (indicated by subscript $0)$ :

$$
K(t)=\frac{e_{G}(t)}{e_{G_{0}}}=\frac{e_{B}(t)}{e_{B_{0}}}(3)
$$

Combining equations (1), (2) and (3), $K(t)$ is expressed as:

$K(t)=\left(f_{G}(t) \times C_{G, 0}+\left(1-f_{G}(t)\right) \times C_{B, 0}\right) / C(t)$

with $C_{G, 0}$ and $C_{B, 0}$ the modern ${ }^{10} \mathrm{Be}$ concentrations in the sand of each river. The mean Himalayan erosion rate $e(t)$ is then determined from the modern erosion rate $e_{0}$ through:

$e(t)=K(t) \times e_{0}$

The resulting mean Himalayan erosion rate $e(t)$ displays a signal similar to the paleoconcentration signal, i.e. an erosion rate constant on average over the last $6.2 \mathrm{Ma}$, between 0.8 and $1.3 \mathrm{~mm} / \mathrm{y}$, close to the modern values of $\sim 1 \mathrm{~mm} / \mathrm{y}$ (Fig. $2 \mathrm{e}, \mathrm{f})$. Under the assumption of a uniform erosive response factor (described above), within 1- $\sigma$ uncertainties 
of $\pm 30 \%$, and despite the variable mixing of the Ganga and Brahmaputra sand, this demonstrates that our data do not point to a long-term increase in erosion rates.

\section{Implications of stable late Cenozoic Himalayan erosion}

Our results indicate that climate forcing of erosion is weak in the Himalayas, as argued from detrital thermochronometry by ref. ${ }^{38}$ and on a global scale by ref. ${ }^{7}$. The marked increase (by a factor two or three) in local erosion rates that is documented by published in situ thermochronometry in the Himalayas ${ }^{5,39,40}$ is not reflected by an increase in the mean erosion rates reconstructed using cosmogenic nuclide concentrations in the Bengal Fan. This suggests that available in situ thermochronometric data in the Himalayas are only of local tectonic or geomorphological significance. They do not reflect the average erosion of the Central and Eastern Himalayas as cosmogenic nuclides applied on sediment do.

In mountain ranges, the extension of ice during the late Cenozoic climate cooling likely produced an increase in erosion rates $^{5,6}$ or at least an increase in the variability of erosion rates deduced from several ${ }^{10} \mathrm{Be}$ records ${ }^{14,41,42}$. In the High Himalaya, prominent glacially shaped valleys attest for the intensity of glacial erosion. However, our results do not indicate any significant increase in average erosion rates since $6.2 \mathrm{Ma}$. They even point to a slight decrease since $0.45 \mathrm{Ma}$. Paradoxically, the amplitude of the variations of the ${ }^{10} \mathrm{Be}$ erosion rates is lower during the intensification of the Northern Hemisphere Glaciations (since $\sim 0.8 \mathrm{Ma}$ ) than it was during the previous period. This might partly arise from buffering effects caused by glacio-eustatic variations and temporary sediment storage in the delta, as shown since $11 \mathrm{ka}^{43}$. In any case, our results suggest that glacial erosion had no manifest impact on the global volume of the sediment exported from the Central and Eastern Himalayas.

In this context, the fluctuations of the ${ }^{10} \mathrm{Be}$ paleoconcentrations and $\mathrm{Sr}-\mathrm{Nd}$ provenances between 1.8 and $4.5 \mathrm{Ma}$ (Fig. 2f) could reflect strong responses of the landscape to local changes in tectonics. While the uplift of the Eastern Syntaxis ${ }^{40,44,45}$ could introduce more variability in the sedimentary signal, the rise of the Shillong Plateau ${ }^{46}$ and the development of the Indo-Burman wedge ${ }^{47}$ probably modified the course of the 
Brahmaputra $^{48}$, as well as the size and subsidence of its plain and of the delta. To specify those possible tectonic imprints, additional constraints are necessary to complement the scenario developed in this work. Further studies applied to the eastern Himalayan foreland with an approach similar to ours should yield such constraints.

\section{References}

1. Hay, W.W., Sloan, J.L. \& Wold, C.N. Mass/age distribution and composition of sediments on the ocean floor and the global rate of sediment subduction. J. Geophys. Res. 93, 14933-14940 (1988).

2. Molnar, P. \& England, P. Late Cenozoic uplift of mountain ranges and global climate change: chicken or egg? Nature 346, 29-34 (1990).

3. Zhang, P.Z., Molnar, P. \& Downs, W.R. Increased sedimentation rates and grain sizes 2$4 \mathrm{Myr}$ ago due to the influence of climate change on erosion rates. Nature 410, 891897 (2001).

4. Molnar, $P$. Late Cenozoic increase in accumulation rates of terrestrial sediment: how might climate change have affected erosion rates? Annu. Rev. Earth. PI. Sc. 32, 67-89 (2004).

5. Herman, F. et al. Worldwide acceleration of mountain erosion under a cooling climate. Nature 504, 423-426 (2013).

6. Pedersen, V.K. \& Egholm, D.L. Glaciations in response to climate variations preconditioned by evolving topography. Nature 493, 206-210 (2013).

7. Willenbring, J.K. \& von Blanckenburg, F. Long-term stability of global erosion rates and weathering during late-Cenozoic cooling. Nature 465, 211-214 (2010).

8. Schumer, R. \& Jerolmack, D.J. Real and apparent changes in sediment deposition rates through time. J. Geophys. Res. 114, F00A06 (2009).

9. Schildgen, T.F., van der Beek, P.A., Sinclair, H.D. \& Thiede, R.C. Spatial correlation bias in late-Cenozoic erosion histories derived from thermochronology. Nature 559, 89-93 (2018).

10. Brown, E.T., Stallard, R.F., Larsen, M.C., Raisbeck, G.M. \& Yiou, F. Denudation rates determined from the accumulation of in situ-produced ${ }^{10} \mathrm{Be}$ in the Luquillo experimental forest, Puerto Rico. Earth Planet. Sc. Lett. 129, 193-202 (1995).

11. Granger, D.E., Fabel, D. \& Palmer, A.N. Pliocene-Pleistocene incision of the Green River, Kentucky, determined from radioactive decay of cosmogenic ${ }^{26} \mathrm{Al}$ and ${ }^{10} \mathrm{Be}$ in Mammoth Cave sediments. Geol. Soc. Am. Bull. 113, 825-836 (2001). 
12. Schaller, M. et al. A $30000 \mathrm{yr}$ record of erosion rates from cosmogenic ${ }^{10} \mathrm{Be}$ in Middle European river terraces. Earth Planet. Sc. Lett. 204, 307-320 (2002).

13. Bierman, P.R., Shakun, J.D., Corbett, L.B., Zimmerman, S.R. \& Rood, D.H. A persistent and dynamic East Greenland Ice Sheet over the past 7.5 million years. Nature 540, 256-260 (2016).

14. Puchol, N. et al. Limited impact of Quaternary glaciations on denudation rates in Central Asia. Geol. Soc. Am. Bull. 129 (3-4), 479-499 (2017).

15. Raup, B. et al. The GLIMS geospatial glacier database: A new tool for studying glacier change. Global Planet. Change 56, 101-110 (2007).

16. Shi, Y. Characteristics of late Quaternary monsoonal glaciation on the Tibetan Plateau and in East Asia. Quatern. Int. 97-98, 79-91 (2002).

17. An, Z. et al. Glacial-Interglacial Indian Summer Monsoon Dynamics. Science 333, 719 723 (2011).

18. Curray, J.R., Emmel, F.J. \& Moore, D.G. The Bengal Fan: morphology, geometry, stratigraphy, history and processes. Mar. Petrol. Geol. 19, 1191-1223 (2003).

19. Schwenk, T. \& Spiess, V. Architecture and stratigraphy of the Bengal Fan as response to tectonic and climate revealed from high-resolution seismic data. SEPM Spec. P. 92, 107-131 (2009).

20. Clemens, S.C. et al. Expedition 353 summary. Proc. IODP 353, 1-32 (2016).

21. France-Lanord, C. et al. Expedition 354 summary. Proc. IODP 354, 1-35 (2016).

22. Bergmann, F., Schwenk, T., Spiess, V., \& France-Lanord, C. Middle to Late Pleistocene Architecture and Stratigraphy of the Lower Bengal Fan-Integrating Multichannel Seismic Data and IODP Expedition 354 Results. Geochem. Geophy. Geosy. 21(1), 397 (2019).

23. Brown, E.T. et al. Examination of surface exposure ages of Antarctic moraines using in situ produced ${ }^{10} \mathrm{Be}$ and ${ }^{26} \mathrm{Al}$. Geochim. Cosmochim. Ac. 55, 2269-2283 (1991).

24. Arnold, M. et al. The French accelerator mass spectrometry facility ASTER: Improved performance and developments. Nucl. Instrum. Meth. B 268, 1954-1959 (2010).

25. Braucher, R. et al. Preparation of ASTER in-house ${ }^{10} \mathrm{Be} /{ }^{9} \mathrm{Be}$ standard solutions. Nucl. Instrum. Meth. B 361, 335-340 (2015).

26. Weber, M.E. \& Reilly, B.T. Hemipelagic and turbiditic deposits constrain lower Bengal Fan depositional history through Pleistocene climate, monsoon, and sea level transitions. Quat. Sci. Rev.199, 159-173 (2018).

27. Blum, M. et al. Allogenic and Autogenic Signals in the Stratigraphic Record of the DeepSea Bengal Fan. Sci. Rep.-UK 8, 7973 (2018). 
28. Lenard, S.J.P, Cruz, J., France-Lanord, C., Lavé, J. \& Reilly, B.T. Data report: calcareous nannofossils and lithologic constraints on the age model of IODP Site U1450. Proc. IODP 354 (2020, in press).

29. Reilly, B.T. et al., Mid to late Pleistocene evolution of the Bengal Fan: Integrating core and seismic observations for chronostratigraphic modeling of the IODP Expedition 354 $8^{0}$ North transect. Geochemistry, Geophys. Geosystems (2020, in press).

30. Lupker, M. et al. ${ }^{10}$ Be-derived Himalayan denudation rates and sediment budgets in the Ganga basin. Earth Planet. Sc. Lett. 333-334, 146-156 (2012).

31. Lupker, M. et al. ${ }^{10} \mathrm{Be}$ systematics in the Tsangpo-Brahmaputra catchment: the cosmogenic nuclide legacy of the eastern Himalayan syntaxis. Earth Surf. Dynam. 5, 429-449 (2017).

32. Hein, C.J. et al. Post-glacial climate forcing of surface processes in the GangesBrahmaputra river basin and implications for carbon sequestration. Earth Planet. Sc. Lett. 478, 89-101 (2017).

33. Galy, A. \& France-Lanord, C. Higher erosion rates in the Himalaya: Geochemical constraints on riverine fluxes. Geology 29, 23-26 (2001).

34. Singh, S.K., Rai, S.K. \& Krishnaswami, S. Sr and Nd isotopes in river sediments from the Ganga Basin: Sediment provenance and spatial variability in physical erosion. J. Geophys. Res. 113, F03006 (2008).

35. Singh, S.K. \& France-Lanord, C. Tracing the distribution of erosion in the Brahmaputra watershed from isotopic compositions of stream sediments. Earth Planet. Sc. Lett. 202, 645-662 (2002).

36. Lauer, J. \& Willenbring, J. Steady state reach-scale theory for radioactive tracer concentration in a simple channel/floodplain system. Geophy. Res. 115, F04018 (2010).

37. Contreras-Rosales, L.A. et al. Origin and fate of sedimentary organic matter in the northern Bay of Bengal during the last 18ka. Global Planet. Change 146, 53-66 (2016).

38. Huyghe et al. Rapid exhumation since at least $13 \mathrm{Ma}$ in the Himalaya recorded by detrital apatite fission-track dating of Bengal fan (IODP Expedition 354) and modern Himalayan river sediments. Earth Planet. Sc. Lett. 534, 116078 (2020).

39. Huntington, K.W., Blythe, A.E. \& Hodges, K.V. Climate change and Late Pliocene acceleration of erosion in the Himalaya. Earth Planet. Sc. Lett. 252, 107-118 (2006).

40. Yang, R., Herman, F., Fellin, M.G. \& Maden, C. Exhumation and topographic evolution of the Namche Barwa Syntaxis, eastern Himalaya. Tectonophysics 722, 43-52 (2018).

41. Schaller, M. et al. Paleoerosion Rates from Cosmogenic ${ }^{10} \mathrm{Be}$ in a $1.3 \mathrm{Ma}$ Terrace Sequence: Response of the River Meuse to Changes in Climate and Rock Uplift. J. Geol. 112, 127-144 (2004). 
42. Haeuselmann, P., Granger, D.E., Jeannin, P.-Y. \& Lauritzen, S.-E. Abrupt glacial valley incision at 0.8 Ma dated from cave deposits in Switzerland. Geology 35, 143-146 (2007).

43. Goodbred, S.L. \& Kuehl, S.A. The significance of large sediment supply, active tectonism, and eustasy on margin sequence development: Late Quaternary stratigraphy and evolution of the Ganges-Brahmaputra delta. Sediment. Geol. 133, 227-248 (2000).

44. Burg, J.-P. et al. Exhumation during crustal folding in the Namche-Barwa syntaxis. Terra Nova 9, 53-56 (1997).

45. Zeitler, P.K. et al. Tectonics and topographic evolution of Namche Barwa and the easternmost Lhasa block, Tibet. Geol. S. Am. S. 507, SPE507-02 (2014).

46. Najman, Y., Bracciali, L., Parrish, R.R., Chisty, E. \& Copley, A. Evolving strain partitioning in the Eastern Himalaya: The growth of the Shillong Plateau. Earth Planet. Sc. Lett. 433, 1-9 (2016).

47. Maurin, T. \& Rangin, C. Structure and kinematics of the Indo-Burmese Wedge: Recent and fast growth of the outer wedge. Tectonics 28, TC2010 (2009).

48. Govin, G. et al. Timing and mechanism of the rise of the Shillong Plateau in the Himalayan foreland. Geology 46, 279-282 (2018).

49. Curray, J.R. Possible greenschist metamorphism at the base of a 22-km sedimentary section, Bay of Bengal. Geology 19, 1097-1100 (1991).

50. Radhakrishna, M., Subrahmanyam, C. \& Damodharan, T. Thin oceanic crust below Bay of Bengal inferred from 3-D gravity interpretation. Tectonophysics 493, 93-105 (2010).

\section{Corresponding authors}

Correspondence and requests for materials should be addressed to S.J.P.L.

(sebastien.lenard@gmail.com) or C.F.L. (cfl@crpg.cnrs-nancy.fr).

\section{Acknowledgements}

The samples were provided by IODP (International Ocean Discovery Program). The team of IODP Kochi Core Center is acknowledged for their assistance in sample collection, and the teams of CRPG (Centre de Recherches Pétrographiques et Géochimiques), SARM (Service d'Analyses des Roches et des Minéraux) and CEREGE (Centre de Recherche et d'Enseignement de Géosciences de l'Environnement) for their assistance in sample 
preparation and measurements. The ${ }^{10} \mathrm{Be}$ measurements were performed at the ASTER AMS national facility (Accélérateur pour les sciences de la

terre, environnement, risques, at CEREGE, Aix en Provence), which is supported by the INSU/CNRS (Institut National des Sciences de I'Univers/ Centre National de la Recherche Scientifique), the ANR (Agence Nationale de la Recherche) through the "Projets thématiques d'excellence" program for the "Equipements d'excellence" ASTER-CEREGE action and IRD (Institut de Recherche pour le Développement). The authors acknowledge the support of a Université de Lorraine-CRPG PhD fellowship and a Université de Poitiers A.T.E.R. (Attaché Temporaire d'Enseignement et de Recherche) of S.L., the support of IODP France, and the support of the French Agence Nationale de la Recherche (ANR), under grant ANR-17-CE010018 (Himal Fan project).

\section{Author contributions}

C.F.L. and J.L. designed the study. S.J.P.L., G.A., D.L.B., K.K. performed the measurements. J.L. and S.J.P.L. performed the computations. S.J.P.L., J.L. and C.F.L. interpreted the results and wrote the manuscript. G.A., D.L.B., K.K. are members of the ASTER Team.

\section{Competing Interests}

The authors declare no competing interests. 


\section{Methods}

Material. The IODP Expedition 354 drilled a transect of seven holes in the Middle Bengal Fan extending back to the Miocene at $8^{\circ} \mathrm{N}$ (Fig. 1$)^{21}$. The Bengal Fan turbidites were deposited along a distance of $\sim 3,000 \mathrm{~km}$ south of the Bengal Shelf, as far as $2^{\circ} \mathrm{S}^{18,19,21}$. The cores consist of sand and silt turbidites interbedded with hemipelagic calcareous clay. Expedition 353 provides a complementary turbiditic record in the northwestern Bengal Fan at $16^{\circ} \mathrm{N}^{20}$. Abundant nannofossils, microfossils, and clayey material appropriate for paleomagnetic dating contributed to yield dating constraints over the full period up to recent times $^{20,21,26-29}$.

Abundant quartz-rich sand in the turbidites makes possible the application of in-situproduced ${ }^{10} \mathrm{Be}$ measurement. We selected 28 unconsolidated samples from the inter-levee and sand lobe turbidites from four drilled sites: U1450, U1451 and U1454 at $8^{\circ} \mathrm{N}$, and U1444 at $14^{\circ} \mathrm{N}$ (Fig. 1). The samples cover the $0.07-6.6$ Ma range, with a higher density in the 0.07 - 0.7 Ma range. We also selected five modern bedload samples from the Lower Meghna which export the Ganga and Brahmaputra sediment to the Bay of Bengal. Most samples are rich in the coarse fraction $(>125 \mu \mathrm{m})$.

${ }^{10} \mathrm{Be} /{ }^{9} \mathrm{Be}$ preparation and measurements. A sufficient amount of quartz (> $100 \mathrm{~g}$ for the old samples with a low ${ }^{10} \mathrm{Be}$ concentration) was prepared and decontaminated from the atmospheric ${ }^{10} \mathrm{Be}$ contribution at CRPG-CNRS-UL (Nancy, France) $)^{14,23,30,31}$. The ${ }^{10} \mathrm{Be} /{ }^{9} \mathrm{Be}$ ratios were measured on the $125-250$ or $75-125 \mu \mathrm{m}$ fraction at the ASTER national Accelerator Mass Spectrometer facility (CEREGE, Aix-en-Provence, France) ${ }^{24}$, and normalised to the in-house standard STD-11, using an assigned ${ }^{10} \mathrm{Be} /{ }^{9} \mathrm{Be}$ ratio of $(1.191 \pm$ $0.013) \times 10^{-11}$ (ref. ${ }^{25}$ ). We performed duplicate analyses on five samples to confirm that the grain size plays a minor role in the dispersion of data (Extended Data Fig. 7). Natural ${ }^{9} \mathrm{Be}$ content in quartz might interfere with the ${ }^{9} \mathrm{Be}$ content of the carrier ${ }^{31}$. We measured ${ }^{9} \mathrm{Be}$ concentrations after dissolution using ICP-MS at CRPG, Nancy. They are close to the concentrations predicted from the added carrier, which confirms that the natural ${ }^{9} \mathrm{Be}$ content is negligible. 
The blank-correction (average measured ${ }^{10} \mathrm{Be} /{ }^{9} \mathrm{Be}=5.25 \times 10^{-5}$ atom $/ \mathrm{g}$ ) represents an average correction of 8 and $14 \%$ for samples $<1.8 \mathrm{Ma}$ and for samples $>1.8 \mathrm{Ma}$, respectively. Using a Monte Carlo approach (10'000 iterations), we propagated the uncertainties of: (1) the analytical measurement of the ${ }^{10} \mathrm{Be} /{ }^{9} \mathrm{Be}$ ratio, (2) the blank, (3) the quartz mass, (4-5) the carrier mass and concentration. Average uncertainty is $12 \%$ and $27 \%$ for samples $<1.8 \mathrm{Ma}$ and for samples $>1.8 \mathrm{Ma}$, respectively. The bulk of uncertainty (> $90 \%$ ) is analytic, except for a few samples with low analytical uncertainties.

${ }^{10} \mathrm{Be}$ paleoconcentrations. The ${ }^{10} \mathrm{Be}$ paleoconcentrations correspond to concentrations (Extended Data Fig. 1) corrected for radioactive decay $\left({ }^{10} \mathrm{Be}\right.$ half-life $\left.\mathrm{e}^{51,52:}: 1.387 \pm 0.012 \times 10^{6} \mathrm{y}\right)$. They integrate the ${ }^{10} \mathrm{Be}$ signal acquired during erosion and additional exposure to cosmic rays during sediment transport. In the Ganga plain, additional exposure represents less than $10-15 \%$ of the modern signal ${ }^{30,51}$ (i.e. within our analytical uncertainties). We therefore neglect ${ }^{10} \mathrm{Be}$ production during the sediment transfer through the foreland, and any recent exposure since the Bengal Fan sediment is shielded below a $>2,000 \mathrm{~m}$ water column. We assume that the ${ }^{10} \mathrm{Be}$ paleoconcentrations chiefly reflect the mean concentration at the outlet of the Himalayan range. Using a Monte Carlo approach (10'000 iterations), we propagated the uncertainties of: (1) the present ${ }^{10} \mathrm{Be}$ concentration and (2) the age. Except for a few samples, the bulk of uncertainty (>90\%) derives from the uncertainty of the present ${ }^{10} \mathrm{Be}$ concentration, i.e. from the analytical measurement.

To interpret the ${ }^{10} \mathrm{Be}$ paleoconcentrations and erosion rates, we focused on the lowfrequency signal, i.e. the global trend over $6 \mathrm{Ma}$, rather than the high-frequency variability (i.e. below the million years). Our dataset does not contain a sufficient number of samples to explore the effects of orbital cycles, even over the last million years, covered by half of our samples. Dating uncertainties combined with ${ }^{10} \mathrm{Be}$ analytical uncertainties (too high for the lowest concentrations, e.g. in the 1.8-4.3 Ma interval) makes it difficult to further explore the pattern of high-frequency variability. 
Production and erosion rates. We used Basinga ${ }^{61}$ to compute the modern ${ }^{10} \mathrm{Be}$ production rates, considering the neutron, slow muon, and fast muon pathways with constant attenuation lengths. We set the sea level high latitude production rate at the global mean of 4.18 atom $/ \mathrm{g}^{62}$, with factors of $0.9886,0.0027$ and 0.0087 for the neutron, slow and fast muonic contributions ${ }^{63}$. We scaled these rates with the Lal-Stone model ${ }^{64,65}$ modified by ref. 61. Glacial cover shielding correction on production rates amount to $8 \%$ (GLIMS database ${ }^{15}$ ). The ice cover and associated shielding have probably varied significantly since $6 \mathrm{Ma}$, with an apparent impact remaining in the range of our uncertainties. We included neither topographic shielding ${ }^{66}$ nor paleomagnetic variation corrections.

The drainage basins entered into Basinga ${ }^{61}$ exclude the plains covered by Quaternary deposits (elevation < $200 \mathrm{~m}$ ) and the quartz-poor Cretaceous basalts overlying the Indian Craton. For the strictly Himalayan production rates (i.e. Himalaya s.s. and Transhimalaya, Fig. 1), we removed the southern sub-basins covering the Indian Craton, the Shillong Plateau and the Indo-Burman Range (see ref. ${ }^{30}$ ). The ${ }^{10} \mathrm{Be}$ measurements in rivers draining these sub-basins show a sediment flux limited to $\sim 1 \%$ of the Himalayan derived flux ${ }^{30,31,67}$. The Himalayan erosion is approximated with:

$e_{H}=\frac{A_{T} \times e_{T} \pm A_{S} \times e_{S}}{A_{H}} \cong \frac{A_{T}}{A_{H}} \times e_{T}$

with $e$ and $A$ the mean erosion rates and areas of the full basin $(T)$, the Himalayan part of the basin $(H)$ and the southern sub-basins $(S)$.

When the relative contributions of the Ganga and Brahmaputra basins are steady, equation (1) yields valid erosion rates because the other conditions are fulfilled since ca. 4-6 Ma. The variations of the average cosmogenic nuclide production rate have remained within our ${ }^{10} \mathrm{Be}$ uncertainties (Extended Data Fig. 2). Provenance analyses within foreland folded sediment series in Central Himalaya ${ }^{68-70}$ and Eastern Himalaya ${ }^{71,72}$, and paleoaltimetry along northern Himalaya ${ }^{73,74}$ show a stable extent and elevation of the drainage basins. Sediment transfer has no significant impact on the ${ }^{10} \mathrm{Be}$ concentration ${ }^{30}$. Using a Monte Carlo approach (10'000 iterations), we propagated erosion rate uncertainties from the uncertainties of the ${ }^{10} \mathrm{Be}$ paleoconcentration. The bulk of uncertainty derives from the analytical measurement. 
Sr-Nd isotopic measurements. Samples were prepared and measured at CRPG-CNRS-UL (Nancy, France). Bulk aliquots of the samples were collected before ${ }^{10} \mathrm{Be}$ preparation and rinsed with milli-Q water to reduce sea salt contributions. They were powdered and organic matter was removed by combustion at $600^{\circ} \mathrm{C}$. The samples were leached with $10 \%$ acetic acid ${ }^{32,75}$ and prepared to obtain a silicate residue. The ${ }^{87} \mathrm{Sr} /{ }^{86} \mathrm{Sr}$ was measured using a Triton Plus(TM) multi-collector thermal ionization mass spectrometer with NBS-987 as a standard and quality control. ${ }^{143} \mathrm{Nd} /{ }^{144} \mathrm{Nd}$ was measured using a Neptune(TM) plus multi-collector inductively coupled plasma mass spectrometer. The ${ }^{143} \mathrm{Nd} /{ }^{144} \mathrm{Nd}$ was normalised to ${ }^{146} \mathrm{Nd} /{ }^{144} \mathrm{Nd}=0.7219$ using an exponential law and to the $\mathrm{JNdi}-1$ following a pseudo-standard sample-bracketing method (one standard for each 4-5 samples ${ }^{76}$ ). Results are presented with the $\varepsilon_{\mathrm{Nd}}$ notation $^{77}$. We additionally measured $\mathrm{Sr}$ and $\mathrm{Nd}$ concentrations at SARM (Nancy, France $)^{78}$. Results are interpreted in the geological context developed in the Supplementary Information.

Fraction $\mathbf{f}_{\mathrm{G}}$. Deriving erosion rates that integrate the signal throughout the Himalaya s.s. and the Transhimalaya requires to calculate $f_{G}$ with poles based on the composition of the sediment of the Ganga River at Harding Bridge and the Brahmaputra River at Jamuna Bridge (poles $\mathrm{G}$ and B, Fig. 1). We assumed that these poles have remained stable for the period of study ${ }^{68-74}$. The fraction $f_{G}$ of sand issued from the Ganga Basin is determined applying an equation similar to equation (2) on $\mathrm{Sr}$ and $\mathrm{Nd}$ isotopic compositions. For instance, for $\mathrm{Sr}$ :

$$
\begin{aligned}
& {\left[{ }^{87} \mathrm{Sr}\right]=f_{G} \times\left[{ }^{87} \mathrm{Sr}\right]_{G}+\left(1-f_{G}\right) \times\left[{ }^{87} \mathrm{Sr}\right]_{B}} \\
& \text { and }\left[{ }^{86} \mathrm{Sr}\right]=f_{G} \times\left[{ }^{86} \mathrm{Sr}\right]_{G}+\left(1-f_{G}\right) \times\left[{ }^{86} \mathrm{Sr}\right]_{B}
\end{aligned}
$$

When combined, the equations lead to (ref. ${ }^{54}$, p. 319):

$$
\frac{{ }^{87} S r}{{ }^{86} S r}=\frac{f_{G} \times[S r]_{G} \times \frac{{ }^{87} S r}{{ }^{86} S r_{G}}+\left(1-f_{G}\right) \times[S r]_{B} \times \frac{{ }^{87} S r}{{ }^{86} S r}{ }_{B}}{f_{G} \times[S r]_{G}+\left(1-f_{G}\right) \times[S r]_{B}}
$$

and similarly for $\mathrm{Nd}$.

Because the inversion of $f_{G}$ is overdetermined by the two mixing equations on ${ }^{87} \mathrm{Sr} /{ }^{86} \mathrm{Sr}$ 
and $\varepsilon_{\mathrm{Nd}}$, we compute the mean and $1-\sigma$ uncertainty of $f_{G}$ from the probability density function of $f_{G}$ obtained using equations 1.60 to 1.80 of ref. ${ }^{80}$ :

$p d f=\iint \exp \left(-\frac{1}{2} \times\left(\Psi_{S r}^{2}+\Psi_{N d}^{2}\right)\right) h_{G} h_{B} d x_{G} d x_{B}$

with $h_{G}$ and $h_{B}$ the multivariate density function of each pole, and

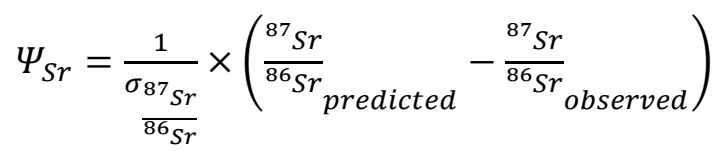

$\Psi_{N d}=\frac{1}{\sigma_{\varepsilon_{N d}}} \times\left(\varepsilon_{N d_{\text {predicted }}}-\varepsilon_{N d_{\text {observed }}}\right)$

with $\frac{\sigma_{87} S r}{{ }^{86} S r}$ and $\sigma_{\varepsilon_{N d}}$ the mean uncertainties on the isotopic signatures of the Ganga and Brahmaputra poles.

For samples without isotopic measurements, the difference of the $\mathrm{Sr}$ concentration between the Ganga and Brahmaputra sediment and the resulting close relationship ${ }^{79}$ between the $\mathrm{Sr}$ concentration and ${ }^{87} \mathrm{Sr} /{ }^{86} \mathrm{Sr}$ are used to estimate $f_{G}$ (Extended Data Fig. 3). There is no such marked difference for the $\mathrm{Nd}$ concentration.

One- $\sigma$ uncertainties range between 0.10 and 0.35 points of $f_{G}$ and were derived from the $p d f$ of $f_{G}$ of each sample, which takes into account for the Ganga and the Brahmaputra poles the uncertainties of: (1) the ${ }^{87} \mathrm{Sr} /{ }^{86} \mathrm{Sr}$ and the $\varepsilon_{\mathrm{Nd}}$, or (2) the $\mathrm{Sr}$ concentration. The analytic uncertainties of the sample measurements were considered negligible compared to the uncertainties of each pole.

Eight Bengal Fan samples and three Lower Meghna samples present negative values for $f_{G}$. This indicates that they were generated during periods with a relative contribution of Transhimalaya higher than the one observed in the sediment of the Brahmaputra at Jamuna Bridge, and comparable to the one observed in the Brahmaputra at Dibrugarh (Fig 2). When computed with a pole based on the Brahmaputra at Dibrugarh, the lowest values of $f_{G}$ fall in the $5-30 \%$ range. This range fits the low contribution of Ganga sand as exposed by our geochemical and granulometric budget and the high contribution of Brahmaputra sediment, 
representing $2 / 3$ of the total flux in modern times (Extended Data Fig. 4 and refs. ${ }^{51,81}$ ). The interpretation of the $f_{G}$ variations is detailed in the Supplementary Information.

Geochemical budget in the Ganga. Combining a geochemical budget with a granulometric budget makes it possible to assess the sequestered flux of sediment in the modern Ganga floodplain and highlight the preferential sequestration of the sand fraction. Here, these budgets are focused on the transfer system from the Narayani-Gandak mountain outlet to the Ganga plain outlet, the Gandak being a tributary of the Ganga (Fig. 1). Following ref. ${ }^{51}$, we compared the sediment content in the immobile elements (i.e. for which the dissolution flux is negligible) $\mathrm{Al}$ and Fe at the range outlet and the plain outlet, and budgeted the sequestration flux by considering the same elements in the sediment deposited in the plain (Extended Data Fig. 4a). The geochemical signature of Himalayan rivers at the range outlet is estimated from 2010s monsoonal data in the Narayani-Gandak at the Himalayan front ${ }^{53}$, and integrated over time and across channel section, following ref. ${ }^{51}$. The signature of the plain outlet was estimated by ref. ${ }^{51}$ for the Ganga at Harding Bridge (Fig. 1). The signature of the sediment deposited in the plain is determined from $\sim 80$ samples of sediment of the Gandak Fan drilled cores $^{54}$, which correspond to sediment deposition since ca. $50 \mathrm{ka}$, and from $\sim 30$ samples of Siwalik sandstone deposited by the Narayani-Gandak system since the late Miocene ${ }^{55}$.

While our assessment of the geochemical signatures for the range outlet and the deposited sediment (Extended Data Fig. 4a) falls within the error bars of the poles approximated by ref. ${ }^{51}$ (their Fig. 15), we obtain sediment budget values significantly higher: $\sim 30 \%$ (instead of their $\sim 10 \%$ ) of the sediment issued from the range ( $165 \mathrm{Mt} / \mathrm{y})$ would be sequestered in the Ganga plain.

Granulometric budget in the Ganga. Discrete granulometric measurements have been conducted for variable depth and discharge values in the Narayani ${ }^{53}$ and the $\mathrm{Ganga}^{51}$. Through adequate interpolation ${ }^{51,53}$, we performed integrations over time and channel crosssections and provide the average grain size distribution of the whole sediment transported by each river (Extended Data Fig. 4b). The coarse sediment fraction (> $125 \mu \mathrm{m})$ represents 
$\sim 40 \%$ of the sediment exported by the Narayani at the range outlet. Contrastingly, the coarse fraction represents only $\sim 20 \%$ of the sediment transported by the Ganga at Harding Bridge, i.e. the plain outlet.

Given a sediment sequestration higher than previously estimated (geochemical budget) and the preferential sequestration of the coarse fraction (granulometric budget), we estimate that $\sim 60 \%$ of the coarse fraction $(>125 \mu \mathrm{m}$ ) of the sediment issued from the Central Himalaya is deposited in the Ganga plain and does not reach the Lower Meghna. This could explain why the Lower Meghna sediment does not contain bedload marked by the isotopic signature of the Ganga.

Because of a lack of data, we cannot perform similar geochemical and granulometric budgets for the Brahmaputra plain. We assume that sand sequestration is limited in the Brahmaputra plain because the Brahmaputra plain has little accommodation space (Fig. 1, e.g. ref. ${ }^{82}$ ). In that case, the Brahmaputra sand would dilute the Ganga sand, an effect reinforced by the fact that the Brahmaputra has a sediment load 1.75 to 2 times higher than the Ganga according to the measured fluxes of suspended load ${ }^{51,81}$ or ${ }^{10} \mathrm{Be}$ derived erosional fluxes $^{30,31}$. The addition of Ganga sand sequestration and dilution by the Brahmaputra sand would mean that the sediment mix in the Lower Meghna would only contain $\sim 13 \%$ of Ganga sand.

This configuration of the Brahmaputra plain might have been different before the rise of the Shillong Plateau ${ }^{46}$ and the growth of the Indo-Burman wedge ${ }^{47}$, which might have favoured a sequestration of the coarse fraction in the Brahmaputra plain higher than in modern times.

Test of the climate forcing hypothesis. In case of a variable mixing in the foreland (differential sequestration) or in the shelf (separate turbiditic systems), the ${ }^{10} \mathrm{Be}$ concentration of the sandy fraction of the Lower Meghna River or the one of the Bengal Fan turbidites can be written from a mixing perspective:

$C=f_{G} \times C_{G}+\left(1-f_{G}\right) \times C_{B}$ 
with $\boldsymbol{C}_{\boldsymbol{G}}$ and $\boldsymbol{C}_{\boldsymbol{B}}$ the ${ }^{10} \mathrm{Be}$ concentrations of the Ganga and Brahmaputra sand respectively. At steady state, these concentrations depend on the mean erosion rates in the basins of these rivers according to:

$C_{G}=\sum_{i=1,3} \frac{\Lambda_{i} \times P_{G, i}}{\rho \times e_{G}}$

and

$C_{B}=\sum_{i=1,3} \frac{\Lambda_{i} \times P_{B, i}}{\rho \times e_{B}}$

with $\Lambda_{i}$ the attenuation lengths of nucleons or muons, $\rho$ the density of eroded rocks, $P_{G, i}$ and $P_{B, i}$ the mean nucleogenic and muogenic cosmogenic nuclide production rates in the respective drainage basins, and $e_{G}$ and $e_{B}$ the mean erosion rates in the basins (e.g. ref. ${ }^{14}$ ). It follows:

$C=\sum_{i=1,3} \frac{\Lambda_{i}}{\rho} \times\left(f_{G} \times \frac{P_{G, i}}{e_{G}}+\left(1-f_{G}\right) \times \frac{P_{B, i}}{e_{B}}\right)(4)$.

If the Ganga and Brahmaputra sediments are fully exported to the Bengal Fan, the proportion:

$f_{G}=\frac{A_{G} \times e_{G}}{A_{B} \times e_{B}+A_{G} \times e_{G}}$

$A_{G}$ and $A_{B}$ being the areas of the basins, and the above equation simplifies to the classical equation:

$C=\frac{1}{e} \times \sum_{i=1,3} \frac{\Lambda_{i} \times P_{i}}{\rho}$

with $P_{i}$ and $e$ the mean nucleogenic and muogenic production and erosion rates over the whole basin of the Lower Meghna. Otherwise, equation (4) cannot be simplified and leads to the indeterminacy of the mean erosion rate.

To overcome the indeterminacy, we chose to test a scenario in which all the Himalayan landscapes would similarly respond to a regional forcing, i.e. in which $e_{G}$ and $e_{B}$ co-vary:

$e_{G}(t)=K(t) \times e_{G, 0}$

and 
$e_{B}(t)=K(t) \times e_{B, 0}$

with $e_{G, 0}$ and $e_{B, 0}$ the modern erosion rates of the Ganga and Brahmaputra basins respectively and $K(t)$ the regional amplification factor.

In that case, assuming a negligible variation of production rates over the period of study (Extended Data Fig. 2), the mean erosion rate of the Lower Meghna Basin is derived from equation (4):

$e(t)=K(t) \times e_{0}=K(t) \times \frac{A_{G} \times e_{G, 0}+A_{B} \times e_{B, 0}}{A_{G}+A_{B}}$,

with $e_{0}$ the mean modern erosion rate of the Lower Meghna Basin and

$K(t)=\frac{1}{C(t)} \times \sum_{i=1,3} \frac{\Lambda_{i}}{\rho} \times\left(f_{G}(t) \times \frac{P_{G, i}}{e_{G, 0}}+\left(1-f_{G}(t)\right) \times \frac{P_{B, i}}{e_{B, 0}}\right)$

in other terms:

$K(t)=f_{G}(t) \times \frac{C_{G, 0}}{C(t)}+\left(1-f_{G}(t)\right) \times \frac{C_{B, 0}}{C(t)}$

These equations are also valid when we restrict the Lower Meghna Basin to its Himalayan s.s. and Transhimalayan part to determine the Himalayan erosion rate, as proposed by ref. ${ }^{30,31}$.

However, these equations are difficult to verify when $f_{G}<0$. In that case, we should expect the ${ }^{10} \mathrm{Be}$ concentration of the mixing to be larger than the concentration of the Brahmaputra before the confluence at $31 \times 10^{3}$ atom/g. Since the ${ }^{10} \mathrm{Be}$ concentration of the Brahmaputra at Dibrugarh (Fig. 1) is poorly defined, as well as the concentrations of the Himalayan tributaries of the Brahmaputra that display variable values between $8 \times 10^{3}$ and $41 \times 10^{3}$ atom $/ \mathrm{g}^{31}$, we chose to consider $f_{G}=0$ in equation (5) for those cases (i.e. for six samples of the Bengal Fan in the time span 0.5-0 Ma and for two older samples, and for three samples of the Lower Meghna).

Using a Monte Carlo approach (10'000 iterations), we propagated the uncertainty of: (1) the ${ }^{10} \mathrm{Be}$ paleoconcentration of the samples, (2) the ${ }^{10} \mathrm{Be}$ concentrations of the Ganga and the Brahmaputra, (3) the $f_{G}$. Except for a few samples, the bulk of uncertainty (> $90 \%$ ) derives from the ${ }^{10} \mathrm{Be}$ paleoconcentration, i.e. from the analytical measurement. 
Temporal variability of cosmogenic nuclide production rates. The cosmogenic nuclide production rates depend on the solar activity, stable over the last $10 \mathrm{Ma}^{83}$, and the intensity of Earth's magnetic field ${ }^{84}$. We explored the impact of the temporal variations of Earth's magnetic dipole intensity on production rates in Extended Data Fig. 2. Using different databases of dipole paleointensity, the continuous Muscheler et al.'s (2005) ${ }^{56}$ database from 0 to $60 \mathrm{ka}$, the SINT2000 continuous database ${ }^{57}$ from 60 to $2000 \mathrm{ka}$, and the PINT lava flow discrete database ${ }^{58}$, which has a low resolution for the record $>4 \mathrm{Ma}$, we computed the ${ }^{10} \mathrm{Be}$ production rate normalised to modern values as a function of time, for the elevation distribution of the Himalayan s.s. and Transhimalayan part of the Ganga-Brahmaputra Basin. Calculation was done at a mid-latitude of $28^{\circ} \mathrm{N}$ for the basin, according to the Lal-Stone model $^{64,65}$, and using the magnetic correction ${ }^{85}$.

$\cos \left(\lambda_{M}\right)=\left(\frac{M}{M_{0}}\right)^{1 / 4} \times \cos \left(\lambda_{s}\right)$

where $M$ and $M_{0}$ are the past and present magnetic dipole field intensity, $\lambda_{s}$ is the latitude of the studied site (i.e. $\sim 28^{\circ} \mathrm{N}$ ), and $\lambda_{M}$ an equivalent virtual geomagnetic latitude translated into the Lal-Stone model.

Since 2 or $4.5 \mathrm{Ma}$, the nucleogenic production rate displays significant variations and has an average $10 \%$ higher than in modern times, with a standard deviation of $\sim 15-17 \%$, which remains in the uncertainties of our ${ }^{10} \mathrm{Be}$ results.

Production rates can vary by a maximum factor of two. This variability could partly explain the variability of apparent erosion rates. But given the high frequency of the signal of the paleomagnetic field and given the large uncertainties of the ages of samples, we were not able to correct our concentrations from the variations of the paleomagnetic field and to explore this direction.

\section{Data availability}

The datasets generated and analysed during the current study are available in the Pangaea Repository: https://doi.org/10.1594/PANGAEA.912098 (Sample information, ${ }^{10} \mathrm{Be}$ 
and $\mathrm{Sr}-\mathrm{Nd}$ isotopic results, calculated fractions and erosion rates);

https://doi.org/10.1594/PANGAEA.912100 ( ${ }^{10} \mathrm{Be}$ duplicate results);

https://doi.org/10.1594/PANGAEA.912101 ( ${ }^{10} \mathrm{Be}$ blanks);

https://doi.org/10.1594/PANGAEA.912103 (Major and trace element results);

https://doi.org/10.1594/PANGAEA.912108 (Chemical analyses for river sediment);

https://doi.org/10.1594/PANGAEA.912109 (Sr-Nd and ${ }^{10} \mathrm{Be}$ data from river sediment used for the $\mathrm{f}_{\mathrm{G}}$ and $\mathrm{K}(\mathrm{t})$ computation).

\section{Code availability}

The Matlab(TM) and R codes used in this study are available on request to the corresponding author.

\section{References}

51. Lupker, M. et al. A Rouse-based method to integrate the chemical composition of river sediments: Application to the Ganga basin. J. Geophys. Res. 116, F04012 (2011).

52. Lupker, M. et al. Increasing chemical weathering in the Himalayan system since the Last Glacial Maximum. Earth Planet. Sc. Lett. 365, 243-252 (2013).

53. Morin, G.P. et al. Annual Sediment Transport Dynamics in the Narayani Basin, Central Nepal: Assessing the Impacts of Erosion Processes in the Annual Sediment Budget. J. Geophys. Res. 123, 2341-2376 (2018).

54. Morin, G. L'érosion et l'altération et leur évolution depuis le tardi-Pléistocène : Analyse des processus d'érosion à partir de sédiments de rivière actuels et passés au Népal Central. Université de Lorraine, Nancy (2015).

55. Lenard, S.J.P. The evolution of the Himalaya since the Late Miocene, as told by the history of its erosion (Evolution de l'Himalaya de la fin du Miocène à nos jours à partir de l'Histoire de son érosion). Université de Lorraine, Nancy (2019).

56. Muscheler, R., Beer, J., Kubik, P.W. \& Synal, H.-A. Geomagnetic field intensity during the last 60,000 years based on ${ }^{10} \mathrm{Be}$ and ${ }^{36} \mathrm{Cl}$ from the Summit ice cores and ${ }^{14} \mathrm{C}$. Quat. Sci. Rev. 24, 1849-1860 (2005).

57. Valet, J.-P., Meynadier, L. \& Guyodo, Y. Geomagnetic dipole strength and reversal rate over the past two million years. Nature 435, 802-805 (2005).

58. Biggin, A.J., McCormack, A. \& Roberts, A. Paleointensity database updated and upgraded. Eos 91, 15-16 (2010). 
59. Korschinek, G. et al. A new value for the half-life of ${ }^{10} \mathrm{Be}$ by Heavy-Ion Elastic Recoil Detection and liquid scintillation counting. Nucl. Instrum. Meth. B 268, 187-191 (2010).

60. Chmeleff, J., von Blanckenburg, F., Kossert, K. \& Jakob, D. Determination of the ${ }^{10} \mathrm{Be}$ half-life by multicollector ICP-MS and liquid scintillation counting. Nucl. Instrum. Meth. B 268, 192-199 (2010).

61. Charreau, J. et al. Basinga: A cell-by-cell GIS toolbox for computing basin average scaling factors, cosmogenic production rates and denudation rates. Earth Surf. Process. Landf. 44(12), 2349-2365. (2019).

62. Martin, L.C.P. et al. The CREp program and the ICE-D production rate calibration database: A fully parameterizable and updated online tool to compute cosmic-ray exposure ages. Quat. Geochronol. 38, 25-49 (2017).

63. Braucher, R., Merchel, S., Borgomano, J. \& Bourlès, D.L. Production of cosmogenic radionuclides at great depth: A multi element approach. Earth Planet. Sc. Lett. 309, 19 (2011).

64. Lal, D. Cosmic ray labeling of erosion surfaces: in situ nuclide production rates and erosion models. Earth Planet. Sc. Lett. 104, 424-439 (1991).

65. Stone, J.O. Air pressure and cosmogenic isotope production. J. Geophys. Res. Solid Earth 105, 23753-23759 (2000).

66. DiBiase, R.A. Increasing vertical attenuation length of cosmogenic nuclide production on steep slopes negates topographic shielding corrections for catchment erosion rates. Earth Surf. Dyn. 6(4), 923 (2018).

67. Rosenkranz, R., Schildgen, T., Wittmann, H. \& Spiegel, C. Coupling erosion and topographic development in the rainiest place on Earth: Reconstructing the Shillong Plateau uplift history with in-situ cosmogenic ${ }^{10} \mathrm{Be}$. Earth Planet. Sc. Lett. 483, 39-51 (2018).

68. Huyghe, P., Galy, A., Mugnier, J.-L. \& France-Lanord, C. Propagation of the thrust system and erosion in the Lesser Himalaya: Geochemical and sedimentological evidence. Geology 29, 1007 (2001).

69. Robinson, D.M., DeCelles, P.G., Patchett, P.J. \& Garzione, C.N. The kinematic evolution of the Nepalese Himalaya interpreted from Nd isotopes. Earth Planet. Sc. Lett. 192, 507-521 (2001).

70. Huyghe, P., Mugnier, J.L., Gajurel, A.P. \& Delcaillau, B. Tectonic and climatic control of the changes in the sedimentary record of the Karnali River section (Siwaliks of western Nepal). The Island Arc 14, 311-327 (2005).

71. Chirouze, F. et al. Tectonics, exhumation, and drainage evolution of the eastern Himalaya since $13 \mathrm{Ma}$ from detrital geochemistry and thermochronology, Kameng River Section, Arunachal Pradesh. Geol. Soc. Am. Bull. 125, 523-538 (2013).

72. Bracciali, L. et al. Plio-Pleistocene exhumation of the eastern Himalayan syntaxis and its domal 'pop-up.' Earth-Sci. Rev. 160, 350-385 (2016).

73. Gébelin, A. et al. The Miocene elevation of Mount Everest. Geology 41, 799-802 (2013). 
74. Garzione, C.N. et al. High times on the Tibetan Plateau: Paleoelevation of the Thakkhola graben, Nepal. Geology 28, 339-342 (2000).

75. Galy, A., France-Lanord, C. \& Derry, L.A. The Late Oligocene-Early Miocene Himalayan belt Constraints deduced from isotopic compositions of Early Miocene turbidites in the Bengal Fan. Tectonophysics 260, 109-118 (1996).

76. Yang, Y. et al. Eolian dust forcing of river chemistry on the northeastern Tibetan Plateau since 8 Ma. Earth Planet. Sc. Lett. 464, 200-210 (2017).

77. Goldstein, S.L., O'nions, R.K. \& Hamilton, P.J. A Sm-Nd isotopic study of atmospheric dusts and particulates from major river systems. Earth Planet. Sc. Lett. 70, 221-236 (1984).

78. Carignan, J. et al. Routine Analyses of Trace Elements in Geological Samples using Flow Injection and Low Pressure On-Line Liquid Chromatography Coupled to ICP-MS:

A Study of Geochemical Reference Materials BR, DR-N, UB-N, AN-G and GH. Geostandards Newsletter 25, 187-198 (2001).

79. Goodbred, S.L. et al. Piecing together the Ganges-Brahmaputra-Meghna River delta: Use of sediment provenance to reconstruct the history and interaction of multiple fluvial systems during Holocene delta evolution. Geol. Soc. Am. Bull. 126, 1495-1510 (2014).

80. Tarantola, A. Inverse problem theory and methods for model parameter estimation. Society of Industrial and Applied Mathematics (2005).

81. Delft Hydraulics and Danish Hydraulics Institute, River Survey Project, Flood Action Plan 24 (Water Resour. Plann. Org., Dhaka, 1996).

82. Hetényi, G. et al. Segmentation of the Himalayas as revealed by arc-parallel gravity anomalies. Sci. Rep. 6, 33866 (2016).

83. Leya, I. et al. The production of cosmogenic nuclides in stony meteoroids by galactic cosmic-ray particles. Meteorit. Planet. Sci. 35, 259-286 (2000).

84. Lifton, N. Implications of two Holocene time-dependent geomagnetic models for cosmogenic nuclide production rate scaling. Earth Planet. Sc. Lett. 433, 257-268 (2016).

85. Nishiizumi, K. et al. Cosmic ray production rates of ${ }^{10} \mathrm{Be}$ and ${ }^{26} \mathrm{Al}$ in quartz from glacially polished rocks. J. Geophys. Res. Solid Earth 94, 17907-17915 (1989). 
Extended Data Fig. 1. ${ }^{10} \mathrm{Be}$ uncorrected concentration results.

The theoretical radioactive correction curve from the average ${ }^{10} \mathrm{Be}$ concentration of the Lower Meghna is indicated. Same symbols as Fig. 2, 1-sigma uncertainties.

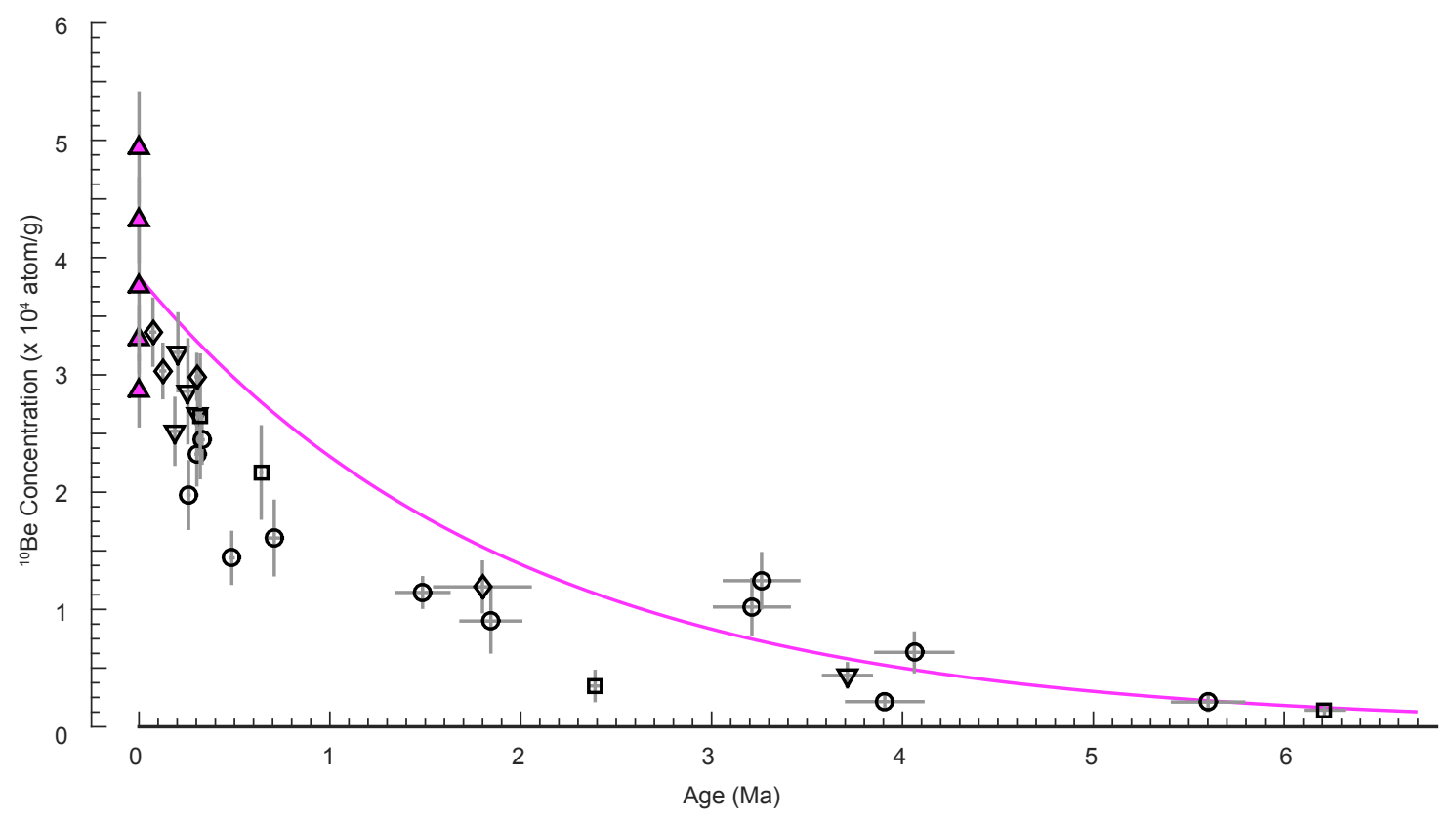


Extended Data Fig. 2. Effect of the variations of the geomagnetic dipole on the ${ }^{10} \mathrm{Be}$ production rate.

a, ${ }^{10} \mathrm{Be}$ production rate normalised to modern values as a function of time, for a basin of Himalayan hypsometry at a latitude of $28^{\circ} \mathrm{N}$. Two dipole temporal databases are explored:

(1) the continuous Muscheler-SINT sediment database ${ }^{56,57}$ and (2) the discrete PINT lava flow database ${ }^{58}$. A 100 ka-long averaging sliding window is applied to the PINT record to buffer the data dispersion and fill the data voids. The resulting curve with the 1-sigma uncertainty envelope is presented.

b, ${ }^{10} \mathrm{Be}$ normalised production rate distribution for the two databases. Despite distinct periods (0-2 Ma vs 0-5 Ma) and resolution ( $0.5 \mathrm{ka}$ vs $\sim 50 \mathrm{ka}$ ), the distribution of both databases is similar for low frequency (period > $100 \mathrm{ka}$ ) signal variations.
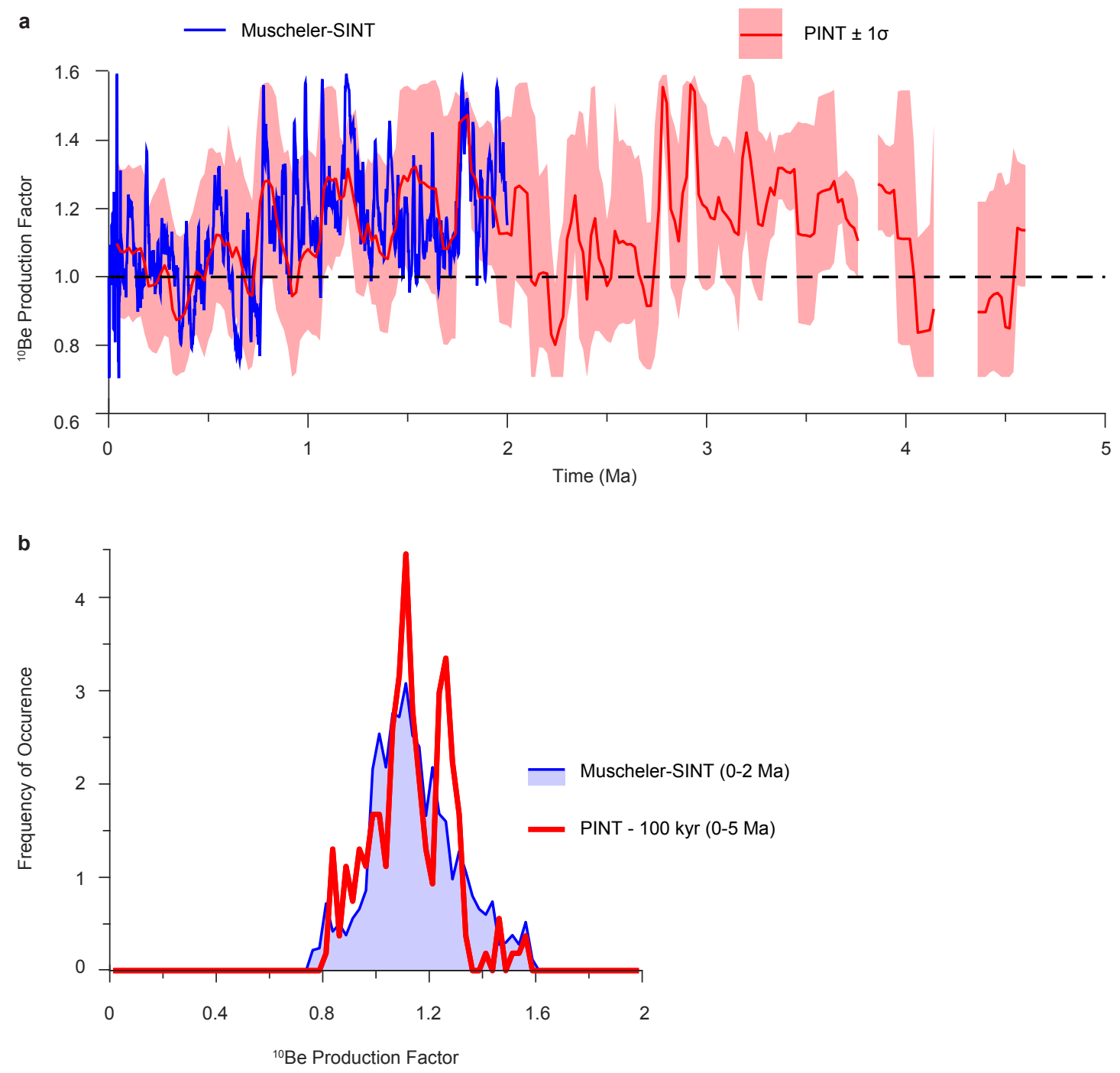


\section{Extended Data Fig. 3. Estimate of $f_{G}$ based on the Sr concentration.}

a, Calibration of the $f_{G}$ obtained using Sr concentration versus the $f_{G}$ obtained using Sr-Nd isotopic data, for the Bengal Fan and the Lower Meghna River samples having both measurements. Thanks to the distinct $\mathrm{Sr}$ concentrations of the Ganga and Brahmaputra sediment (b), this calibration makes it possible to derive a fraction $f_{G}$ for samples having a $\mathrm{Sr}$ concentration measurement without a $\mathrm{Sr}-\mathrm{Nd}$ isotopic measurement. $\mathbf{b}, \mathrm{Sr}$ concentration as a function of $\mathrm{Al} / \mathrm{Si}$, a proxy for granulometry ${ }^{51}$, for the Ganga, Brahmaputra and Lower Meghna bulk sediment (this study and ref. 52). The coarser fraction, i.e. the sandy bedload, of the Lower Meghna sediment overlaps with the composition of Brahmaputra sediment whereas the finer fraction, i.e. the suspended load, corresponds to a mixing of sediment between the Ganga and the Brahmaputra sediment.

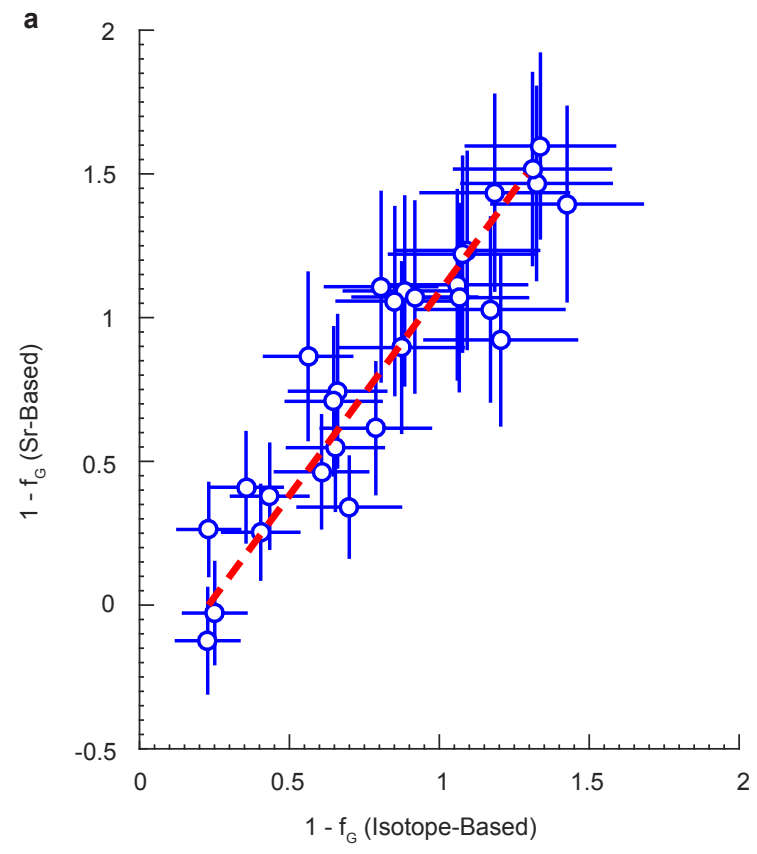

b

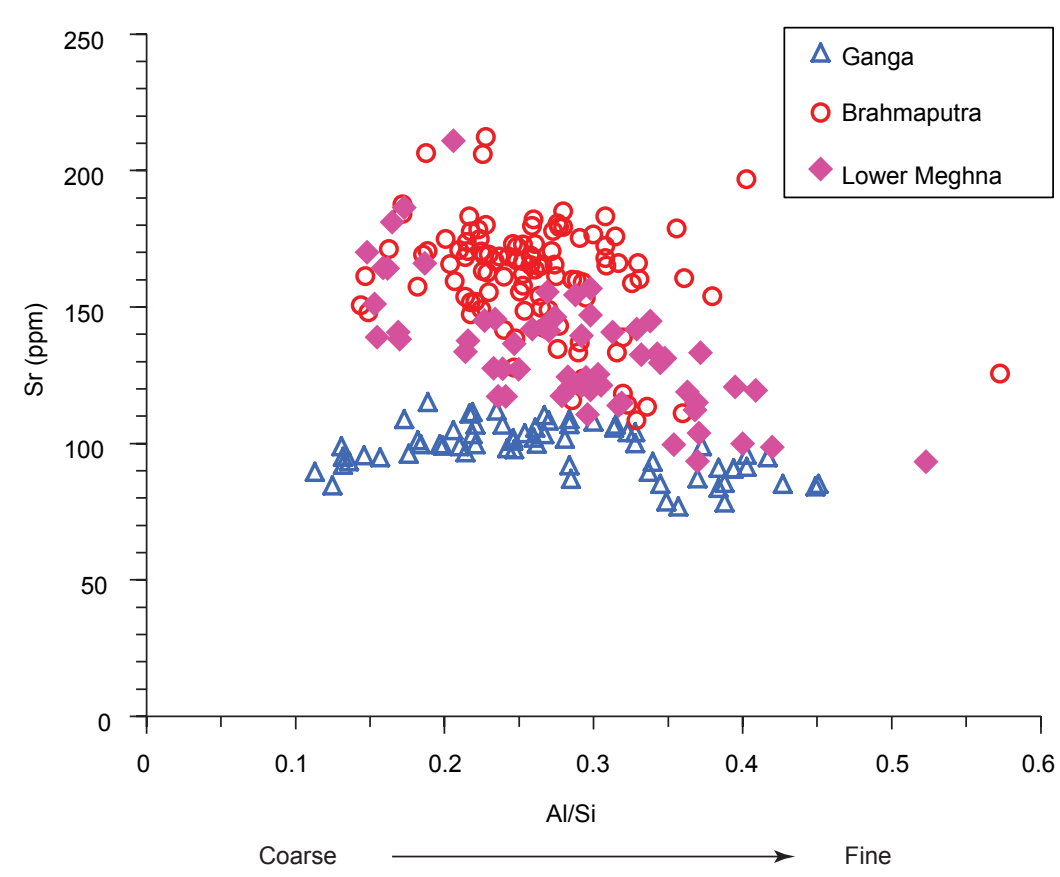




\section{Extended Data Fig. 4. Modern geochemical and granulometric budgets in the}

\section{Ganga plain.}

a, Geochemical budget: Fe/Si vs Al/Si distribution of sediment in the Ganga plain. The geochemical poles for the (1) plain outlet, the (2) range outlet and the (3) plain deposits are represented by colour-filled stars surrounded by border-coloured 1-sigma uncertainty envelopes. While the plain outlet was previously assessed from (1) data of the Ganga at Harding Bridge ${ }^{51}$, we estimated the other poles (Methods) with (2) data from the NarayaniGandak at the Himalayan front ${ }^{53}$ and (3) data from the Gandak megafan and from a new Siwalik section ${ }^{55}$. For comparison, the shaded black stars and envelopes represent the previous approximations of ref. 51 for these poles. b, Granulometric budget: cumulative distribution of grain size (logarithmic scale) for the Ganga and Narayani measured at variable depth and discharge values. The granulometric fraction favoured for Be measurements in this study is $125-250 \mu \mathrm{m}$.

a

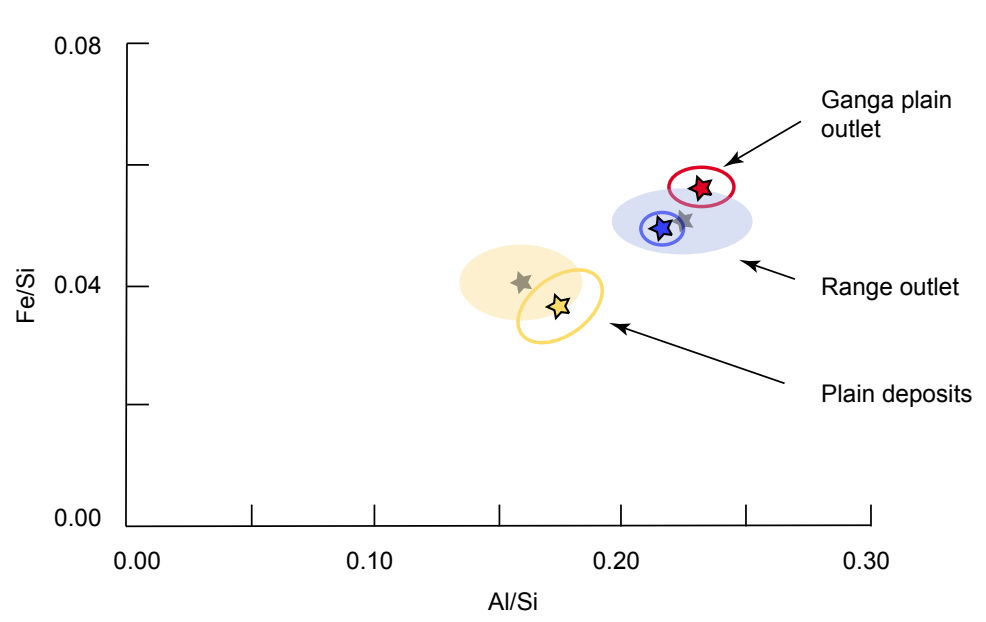

b

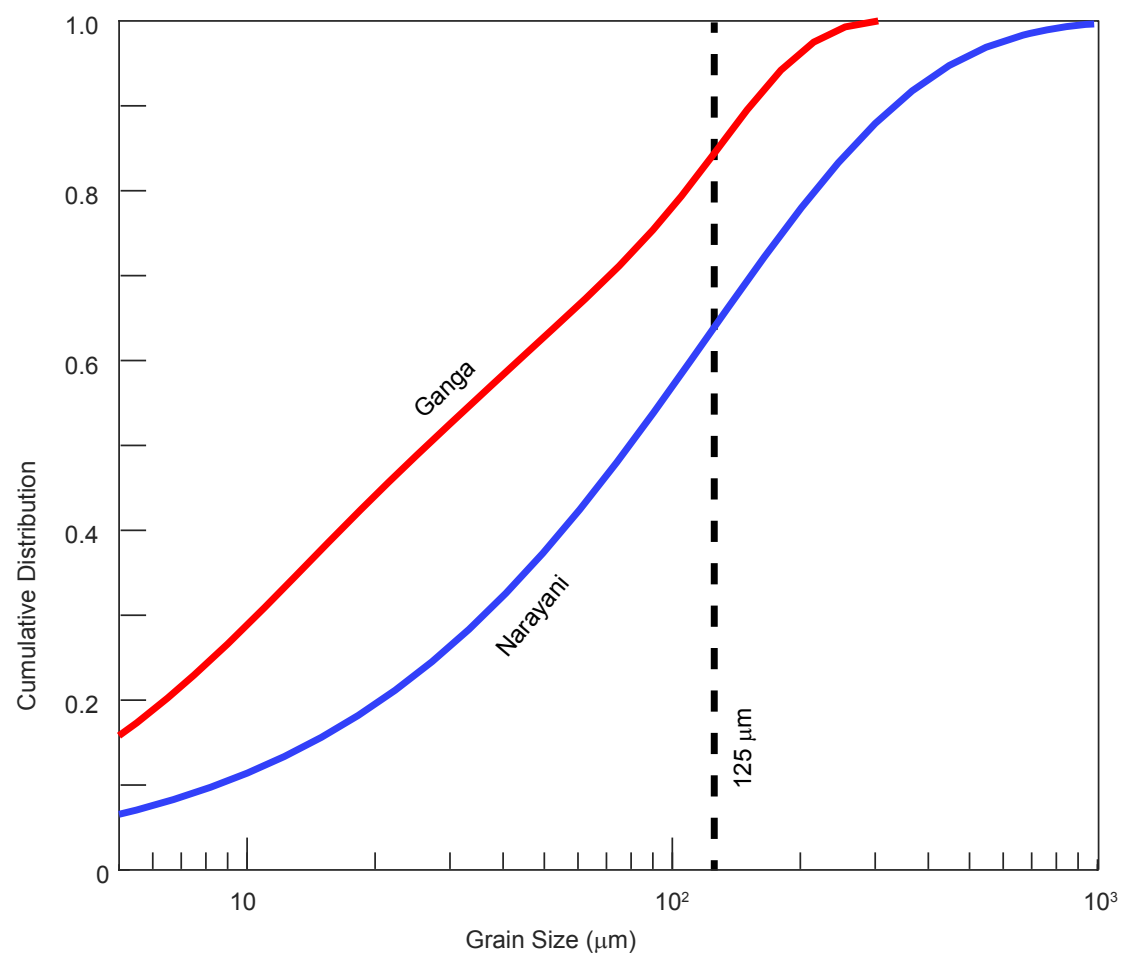




\section{Extended Data Fig. 5. Impact of the variable contribution of Ganga and Brahmaputra}

sediment on ${ }^{10} \mathrm{Be}$ paleoconcentrations.

The chart shows the distribution of ${ }^{10} \mathrm{Be}$ paleoconcentrations of the Bengal Fan and the Lower Meghna River sand as a function of (1) the fraction $f_{G}$ of the Bengal Fan and Lower Meghna sand issued from the Ganga Basin (on the X-axis) and (2) the deposition age of sand (in colour, blue for the Lower Meghna sand, red to yellow for the Bengal Fan sand younger than 0.5 Ma and white to black for the older sand). Each sample is represented by a small dot of colour. For clarity, uncertainties are not presented but are visible in Fig. 2. The average for each interval defined in Fig. 2 is displayed by square dots with 1-sigma uncertainty bars. The modern Ganga ( $G)$ and Brahmaputra (B) poles are shown by pink stars ${ }^{30,31,33-35}$. The zone of potential values obtained by a mixing of modern Ganga and Brahmaputra sand is shown by the pink polygon. Despite some scattering at ca. 2-4 Ma, the values averaged over the intervals seem independent from the fraction of Ganga sand and appear stable.

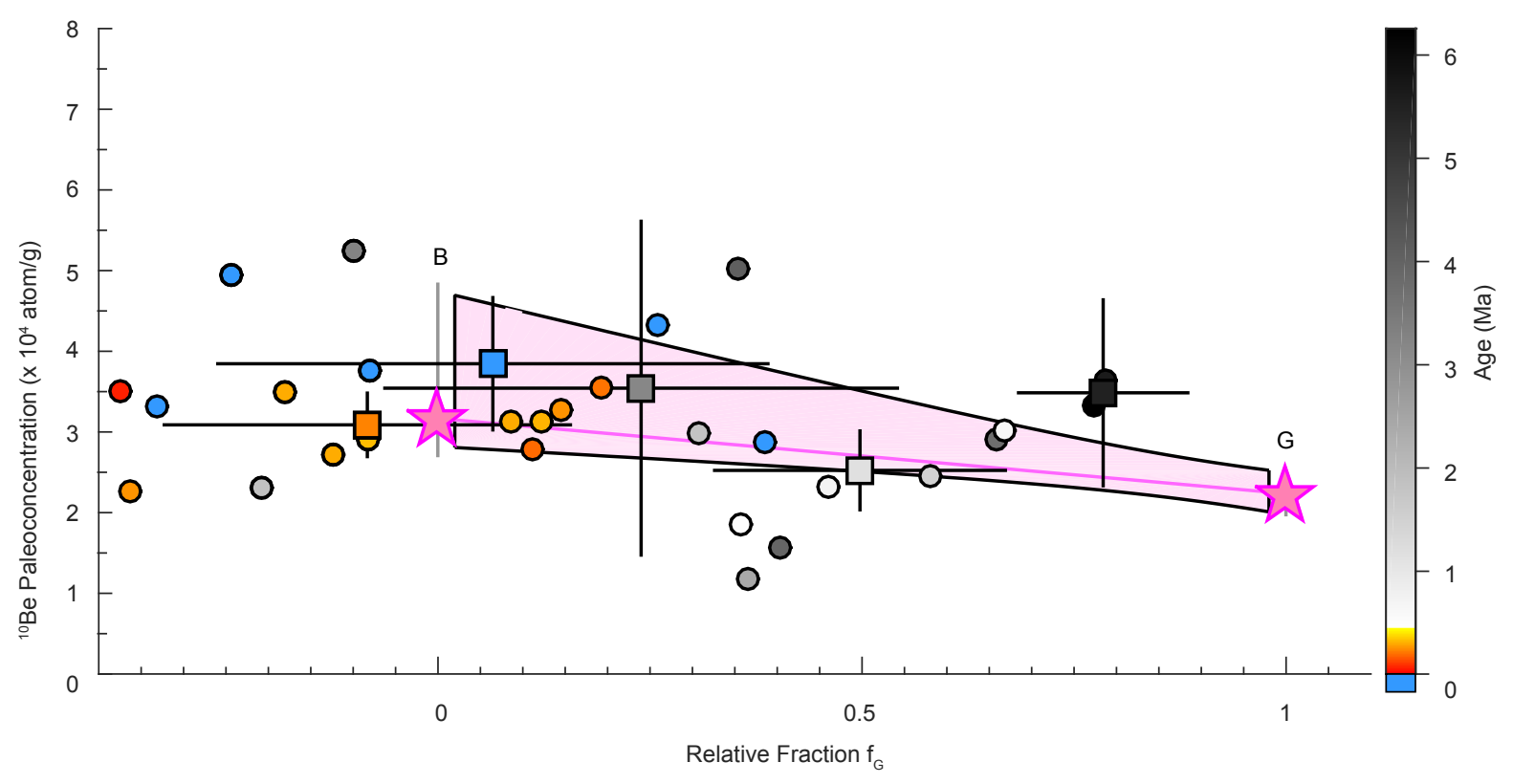


Extended Data Fig. 6. Influence of the selected intervals on averaged results.

One might prefer dividing the period of study according to different averaging intervals than the ones we selected (Fig. 2). For instance, one could merge the 4.5-3.5 Ma interval with the 6.5-4.5 Ma interval. This new division does not alter the evolution of the mean

Be paleoconcentration (a), the mean $\mathrm{f}_{\mathrm{G}}(\mathrm{b})$ and the mean paleoerosion rate $(\mathrm{c})$, and associated conclusions.
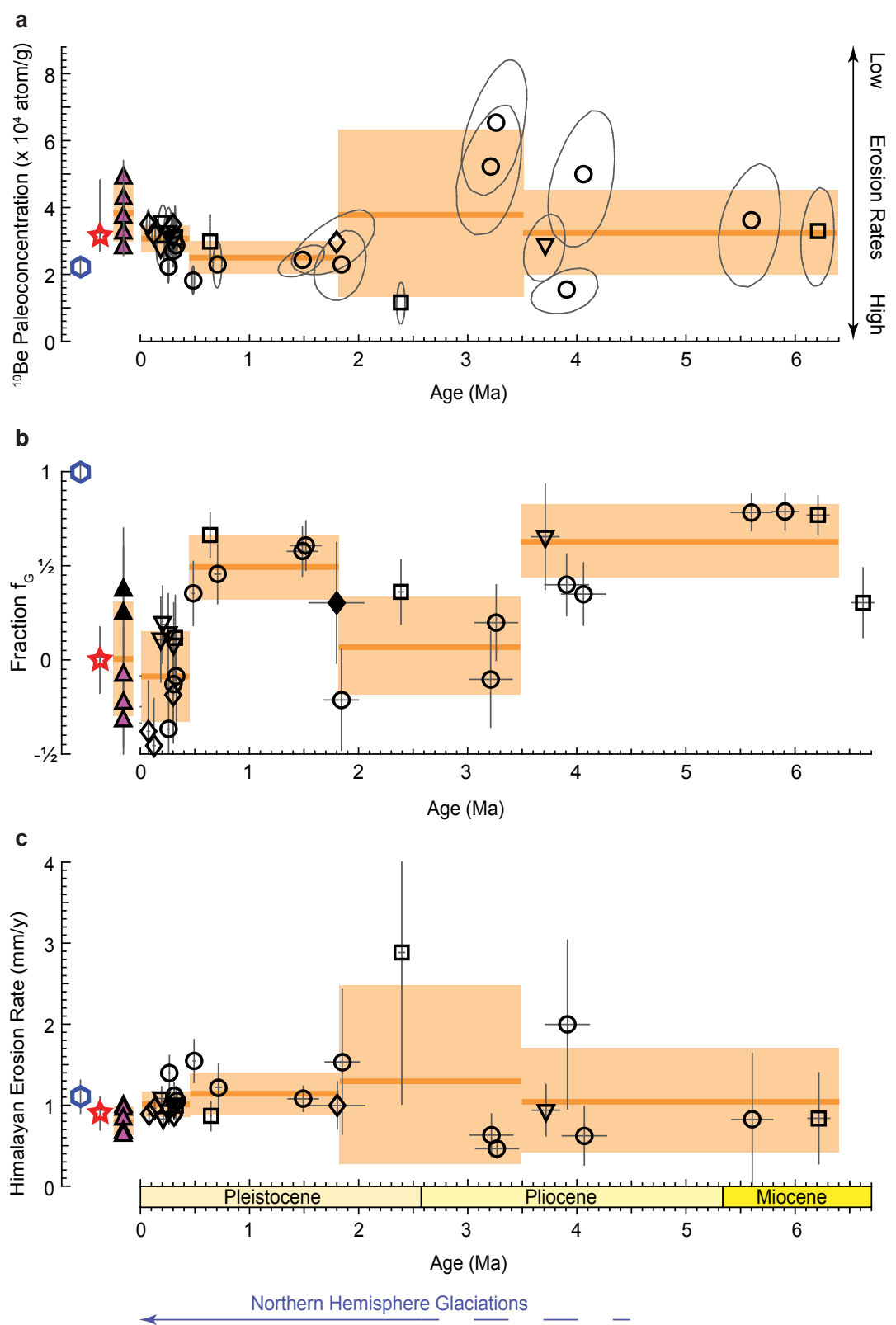


\section{Extended Data Fig. 7. Grain size influence on the ${ }^{10} \mathrm{Be}$ concentration.}

A 75-250 $\mu \mathrm{m}$ fraction was selected for the four samples with little coarse material > $125 \mu \mathrm{m}$. Despite a limited set of analyses in two different size fractions, 75-125 $\mu \mathrm{m}$ and 125-250 $\mu \mathrm{m}$, the grain size does not have a major influence on 10Be concentration (variations by less than $20 \%$ on average). One sample (U1444A-7H) displays a larger value for the coarsest fraction and might be explained by a larger proportion of Brahmaputra coarse sediment in this fraction (modern ${ }^{10} \mathrm{Be}$ concentrations of the Ganga and Brahmaputra sand in Fig. 2b). The overall agreement between the $75-250 \mu \mathrm{m}$ and $125-250 \mu \mathrm{m}$ fractions makes it possible to plot and discuss the data issued from these two granulometric fractions on the same graphs.

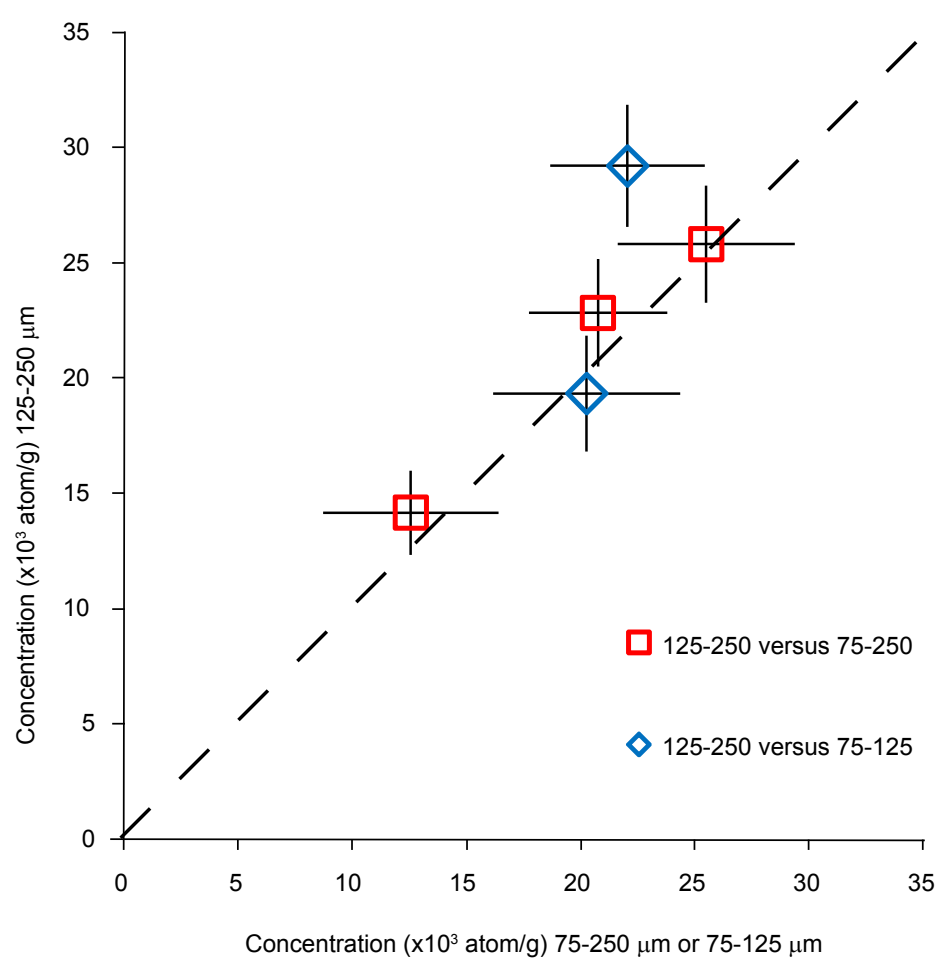


Source data for Fig. 1

\begin{tabular}{|c|c|c|c|c|c|c|c|}
\hline Site & Hole & Core & Sample & Latitude ${ }^{\circ} \mathrm{N}$ & Longitude ${ }^{\circ} \mathrm{E}$ & $\begin{array}{r}\text { Center Core } \\
\text { Depth } \\
\text { Below Sea- } \\
\text { Floor, CSF- } \\
\text { A (m) } \\
\end{array}$ & Reference \\
\hline U1444 & $\mathrm{A}$ & $6 \mathrm{H}$ & 353-U1444A-6H-1W, $100-150 \mathrm{~cm}$. & 14.00 & 84.83 & 46.4 & Ref. 20 \\
\hline U1444 & $\mathrm{A}$ & $7 \mathrm{H}$ & 353-U1444A-7H-5W, $100-150 \mathrm{~cm}$. & 14.00 & 84.83 & 61.9 & Ref. 20 \\
\hline U1444 & A & $9 \mathrm{H}$ & 353-U1444A-9H-5W, 75-130 cm. & 14.00 & 84.83 & 79.6 & Ref. 20 \\
\hline U1444 & $\mathrm{A}$ & $11 \mathrm{H}$ & 353-U1444A-11H-6W, 87-150 cm. & 14.00 & 84.83 & 93.9 & Ref. 20 \\
\hline U1444 & A & $24 \mathrm{~F}$ & $\begin{array}{l}\begin{array}{l}\text { 353-U1444A-24F-3W, 0-56, 65-110 } \\
\mathrm{cm} .\end{array} \\
\end{array}$ & 14.00 & 84.83 & 208.5 & Ref. 20 \\
\hline U1450 & $\mathrm{A}$ & $3 \mathrm{H}$ & 354-U1450A-3H-4W, 50-120 cm. & 8.01 & 87.67 & 16.0 & Ref. 21 \\
\hline U1450 & A & $8 \mathrm{~F}$ & 354-U1450A-8F-2W, 1-60 cm. & 8.01 & 87.67 & 40.8 & Ref. 21 \\
\hline U1450 & $\mathrm{A}$ & $14 \mathrm{~F}$ & 354-U1450A-14F-2W, 90-150 cm. & 8.01 & 87.67 & 70.1 & Ref. 21 \\
\hline U1450 & $\mathrm{A}$ & $25 \mathrm{~F}$ & 354-U1450A-25F-1W, 50-100 cm. & 8.01 & 87.67 & 119.5 & Ref. 21 \\
\hline U1450 & A & $32 \mathrm{~F}$ & 354-U1450A-32F-3W, $24-84 \mathrm{~cm}$. & 8.01 & 87.67 & 155.4 & Ref. 21 \\
\hline U1450 & $\mathrm{A}$ & $40 \mathrm{~F}$ & 354-U1450A-40F-2W, 0-30 cm. & 8.01 & 87.67 & 191.6 & Ref. 21 \\
\hline U1450 & $\mathrm{A}$ & $44 \mathrm{~F}$ & 354-U1450A-44F-3W, 40-100 cm. & 8.01 & 87.67 & 212.6 & Ref. 21 \\
\hline U1450 & $\mathrm{A}$ & $50 \mathrm{~F}$ & 354-U1450A-50F-2W, $86-116 \mathrm{~cm}$. & 8.01 & 87.67 & 239.9 & Ref. 21 \\
\hline U1450 & $\mathrm{A}$ & $83 \mathrm{~F}$ & 354-U1450A-83F-3W, 113-147 cm. & 8.01 & 87.67 & 398.2 & Ref. 21 \\
\hline U1450 & $\mathrm{A}$ & $90 \mathrm{~F}$ & 354-U1450A-90F-3W, $106-136 \mathrm{~cm}$. & 8.01 & 87.67 & 431.0 & Ref. 21 \\
\hline U1450 & $\mathrm{A}$ & $100 \mathrm{~F}$ & 354-U1450A-100F-3W, $28-88 \mathrm{~cm}$. & 8.01 & 87.67 & 477.9 & Ref. 21 \\
\hline U1450 & $\mathrm{A}$ & $110 \mathrm{~F}$ & 354-U1450A-110F-1W, 79-84 cm. & 8.01 & 87.67 & 523.0 & Ref. 21 \\
\hline U1450 & $\mathrm{A}$ & $124 \mathrm{~F}$ & 354-U1450A-124F-3W, $20-80 \mathrm{~cm}$. & 8.01 & 87.67 & 602.2 & Ref. 21 \\
\hline U1450 & $\mathrm{A}$ & $130 \mathrm{~F}$ & 354-U1450A-130F-3W, 0-51 cm. & 8.01 & 87.67 & 630.8 & Ref. 21 \\
\hline U1451 & $\mathrm{A}$ & $9 \mathrm{H}$ & 354-U1451A-9H-2W, $120-145 \mathrm{~cm}$. & 8.01 & 88.74 & 55.1 & Ref. 21 \\
\hline U1451 & $\mathrm{A}$ & $12 \mathrm{~F}$ & 354-U1451A-12F-3W, 90-121 cm. & 8.01 & 88.74 & 69.0 & Ref. 21 \\
\hline U1451 & $\mathrm{A}$ & $22 \mathrm{H}$ & 354-U1451A-22H-5W, 92-126 cm. & 8.01 & 88.74 & 118.1 & Ref. 21 \\
\hline U1451 & $\mathrm{A}$ & $31 \mathrm{~F}$ & 354-U1451A-31F-2W, $44-116 \mathrm{~cm}$. & 8.01 & 88.74 & 199.8 & Ref. 21 \\
\hline U1451 & $\mathrm{A}$ & $39 \mathrm{~F}$ & 354-U1451A-39F-3W, 81-111 cm. & 8.01 & 88.74 & 239.5 & Ref. 21 \\
\hline U1454 & $\mathrm{B}$ & $4 \mathrm{H}$ & 354-U1454B-4H-4W, 0-60 cm. & 8.01 & 85.85 & 29.2 & Ref. 21 \\
\hline U1454 & $\mathrm{B}$ & $6 \mathrm{~F}$ & 354-U1454B-6F-3W, 5-65 cm. & 8.01 & 85.85 & 37.6 & Ref. 21 \\
\hline U1454 & $\mathrm{B}$ & $25 \mathrm{~F}$ & 354-U1454B-25F-2W, $54-114 \mathrm{~cm}$. & 8.01 & 85.85 & 126.4 & Ref. 21 \\
\hline U1454 & $\mathrm{B}$ & $32 \mathrm{~F}$ & 354-U1454B-32F-2W, $80-130 \mathrm{~cm}$. & 8.01 & 85.85 & 159.4 & Ref. 21 \\
\hline $\begin{array}{l}\text { Lower Meghna, Chor } \\
\text { Fasson }\end{array}$ & - & - & BGP 34 & 22.19 & 90.83 & - & Ref. 31 \\
\hline Lower Meghna, Bhola & - & - & BR219 & 22.82 & 90.72 & - & Ref. 51 \\
\hline Lower Meghna, Bhola & - & - & BR446 & 22.82 & 90.72 & - & Ref. 51 \\
\hline Lower Meghna, Daulatkhan & - & - & BR8230 & 22.59 & 90.76 & - & Ref. 51 \\
\hline Padma, Mawa & - & - & BR529 & 23.46 & 90.24 & - & Ref. 51 \\
\hline Padma, Mawa & - & - & BR724 & 23.46 & 90.24 & - & Ref. 51 \\
\hline Ganga, Harding Bridge & - & - & - & 24.05 & 89.02 & - & \begin{tabular}{|l|} 
Ref. \\
$28,31,33$ \\
\end{tabular} \\
\hline Brahmaputra, Sirajganj & - & - & - & 24.47 & 89.73 & - & Ref. 31,32 \\
\hline $\begin{array}{l}\text { Brahmaputra, Jamuna } \\
\text { Bridge }\end{array}$ & - & - & - & 24.39 & 89.80 & - & \begin{tabular}{|l|} 
Ref. \\
$29,31,32$ \\
\end{tabular} \\
\hline Brahmaputra, Dibrugarh & - & - & - & 27.77 & 94.77 & - & Ref. 32 \\
\hline
\end{tabular}


Source data for Fig. 2

\begin{tabular}{|c|c|c|c|c|c|c|c|c|c|}
\hline Site & Sample & $\begin{array}{l}\text { Age } \\
\text { (Ma) }\end{array}$ & $\begin{array}{r}1 \text { sigma } \\
\text { uncertainty } \\
(\mathrm{Ma})\end{array}$ & $\begin{array}{l}\text { Age } \\
\text { model } \\
\text { reference }\end{array}$ & $\begin{array}{l}{ }^{10} \mathrm{Be} \\
\text { paleoconce } \\
\text { ntration } \\
\text { (atom/g) }\end{array}$ & $\begin{array}{l}1 \text { sigma } \\
\text { uncertainty } \\
\text { (atom/g) }\end{array}$ & $\begin{array}{l}\text { Num } \\
\text { ber } \\
\text { of } \\
\text { mea } \\
\text { sure } \\
\text { men } \\
\text { ts }\end{array}$ & Corrections & Reference \\
\hline U1444 & 353-U1444A-6H-1W, $100-150 \mathrm{~cm}$. & 0.19 & 0.025 & 20 & $2.77 \mathrm{E}+04$ & $3.27 \mathrm{E}+03$ & 1 & $\begin{array}{r}\text { radioactive- } \\
\text { decay } \\
\end{array}$ & This study \\
\hline U1444 & 353-U1444A-7H-5W, $100-150 \mathrm{~cm}$. & 0.20 & 0.025 & 20 & $3.54 \mathrm{E}+04$ & $3.67 \mathrm{E}+03$ & 1 & $\begin{array}{r}\text { radioactive- } \\
\text { decay } \\
\end{array}$ & This study \\
\hline U1444 & 353-U1444A-9H-5W, 75-130 cm. & 0.26 & 0.025 & 20 & $3.26 \mathrm{E}+04$ & $5.01 \mathrm{E}+03$ & 1 & $\begin{array}{r}\text { radioactive- } \\
\text { decay } \\
\end{array}$ & This study \\
\hline U1444 & 353-U1444A-11H-6W, 87-150 cm. & 0.31 & 0.025 & 20 & $3.11 \mathrm{E}+04$ & $3.84 \mathrm{E}+03$ & 1 & $\begin{array}{r}\text { radioactive- } \\
\text { decay }\end{array}$ & This study \\
\hline U1444 & $\begin{array}{l}\text { 353-U1444A-24F-3W, 0-56, 65-110 } \\
\mathrm{cm} .\end{array}$ & 3.71 & 0.125 & 20 & $2.89 E+04$ & $6.85 \mathrm{E}+03$ & 1 & $\begin{array}{r}\text { radioactive- } \\
\text { decay }\end{array}$ & This study \\
\hline U1450 & $354-\mathrm{U} 1450 \mathrm{~A}-3 \mathrm{H}-4 \mathrm{~W}, 50-120 \mathrm{~cm}$. & 0.26 & 0.003 & 26,29 & $2.25 \mathrm{E}+04$ & $3.24 \mathrm{E}+03$ & 1 & $\begin{array}{r}\text { radioactive- } \\
\text { decay }\end{array}$ & This study \\
\hline U1450 & $354-U 1450 \mathrm{~A}-8 \mathrm{~F}-2 \mathrm{~W}, 1-60 \mathrm{~cm}$. & 0.30 & 0.004 & 26,29 & $2.71 \mathrm{E}+04$ & $3.06 \mathrm{E}+03$ & 1 & $\begin{array}{r}\text { radioactive- } \\
\text { decay }\end{array}$ & This study \\
\hline U1450 & 354-U1450A-14F-2W, 90-150 cm. & 0.33 & 0.006 & 26,29 & $2.90 \mathrm{E}+04$ & $2.36 \mathrm{E}+03$ & 1 & $\begin{array}{r}\text { radioactive- } \\
\text { decay }\end{array}$ & This study \\
\hline U1450 & $354-\mathrm{U} 1450 \mathrm{~A}-25 \mathrm{~F}-1 \mathrm{~W}, 50-100 \mathrm{~cm}$. & 0.49 & 0.007 & 26,29 & $1.84 \mathrm{E}+04$ & $2.78 \mathrm{E}+03$ & 1 & $\begin{array}{r}\text { radioactive- } \\
\text { decay }\end{array}$ & This study \\
\hline U1450 & 354-U1450A-32F-3W, 24-84 cm. & 0.71 & 0.026 & 26,29 & $2.31 \mathrm{E}+04$ & $4.51 \mathrm{E}+03$ & 1 & $\begin{array}{r}\text { radioactive- } \\
\text { decay }\end{array}$ & This study \\
\hline U1450 & 354-U1450A-40F-2W, 0-30 cm. & 1.49 & 0.138 & 28 & $2.44 \mathrm{E}+04$ & $3.17 \mathrm{E}+03$ & 1 & $\begin{array}{r}\text { radioactive- } \\
\text { decay }\end{array}$ & This study \\
\hline U1450 & 354-U1450A-44F-3W, 40-100 cm. & 1.52 & 0.138 & 28 & - & - & - & - & \\
\hline U1450 & 354-U1450A-50F-2W, 86-116 cm. & 1.84 & 0.157 & 28 & $2.30 \mathrm{E}+04$ & $6.98 \mathrm{E}+03$ & 1 & $\begin{array}{r}\text { radioactive- } \\
\text { decay }\end{array}$ & This study \\
\hline U1450 & 354-U1450A-83F-3W, 113-147 cm. & 3.21 & 0.196 & 28 & $5.24 \mathrm{E}+04$ & $1.31 \mathrm{E}+04$ & 1 & $\begin{array}{r}\text { radioactive- } \\
\text { decay }\end{array}$ & This study \\
\hline U1450 & 354-U1450A-90F-3W, $106-136 \mathrm{~cm}$. & 3.26 & 0.195 & 28 & $6.56 \mathrm{E}+04$ & $1.38 \mathrm{E}+04$ & 1 & $\begin{array}{r}\text { radioactive- } \\
\text { decay }\end{array}$ & This study \\
\hline U1450 & 354-U1450A-100F-3W, 28-88 cm. & 3.91 & 0.200 & 28 & $1.56 \mathrm{E}+04$ & $4.61 \mathrm{E}+03$ & 1 & $\begin{array}{r}\text { radioactive- } \\
\text { decay }\end{array}$ & This study \\
\hline U1450 & 354-U1450A-110F-1W, 79-84 cm. & 4.06 & 0.202 & 28 & $5.02 E+04$ & $1.40 E+04$ & 1 & $\begin{array}{r}\text { radioactive- } \\
\text { decay }\end{array}$ & This study \\
\hline U1450 & 354-U1450A-124F-3W, 20-80 cm. & 5.60 & 0.187 & 28 & $3.63 E+04$ & $1.28 \mathrm{E}+04$ & 1 & $\begin{array}{r}\text { radioactive- } \\
\text { decay }\end{array}$ & This study \\
\hline U1450 & 354-U1450A-130F-3W, 0-51 cm. & 5.91 & 0.122 & 28 & - & - & - & - & \\
\hline U1451 & 354-U1451A-9H-2W, $120-145 \mathrm{~cm}$. & 0.32 & 0.003 & 26,29 & $3.12 \mathrm{E}+04$ & $6.16 \mathrm{E}+03$ & 1 & $\begin{array}{r}\text { radioactive- } \\
\text { decay }\end{array}$ & This study \\
\hline U1451 & $354-U 1451 \mathrm{~A}-12 \mathrm{~F}-3 \mathrm{~W}, 90-121 \mathrm{~cm}$. & 0.64 & 0.001 & 26,29 & $3.00 E+04$ & $5.40 \mathrm{E}+03$ & 1 & $\begin{array}{r}\text { radioactive- } \\
\text { decay }\end{array}$ & This study \\
\hline U1451 & $354-\mathrm{U} 1451 \mathrm{~A}-22 \mathrm{H}-5 \mathrm{~W}, 92-126 \mathrm{~cm}$. & 2.39 & 0.025 & 21 & 1.17E+04 & $4.20 \mathrm{E}+03$ & 1 & $\begin{array}{r}\text { radioactive- } \\
\text { decay }\end{array}$ & This study \\
\hline U1451 & 354-U1451A-31F-2W, 44-116 cm. & 6.21 & 0.100 & 27 & $3.32 E+04$ & $1.02 \mathrm{E}+04$ & 1 & $\begin{array}{r}\text { radioactive- } \\
\text { decay }\end{array}$ & This study \\
\hline U1451 & 354-U1451A-39F-3W, 81-111 cm. & 6.63 & 0.100 & 27 & - & - & - & - & \\
\hline U1454 & 354-U1454B-4H-4W, 0-60 cm. & 0.07 & 0.010 & 26,29 & $3.49 \mathrm{E}+04$ & $2.92 \mathrm{E}+03$ & 1 & $\begin{array}{r}\text { radioactive- } \\
\text { decay }\end{array}$ & This study \\
\hline U1454 & 354-U1454B-6F-3W, 5-65 cm. & 0.13 & 0.010 & 26,29 & $3.23 E+04$ & $2.43 \mathrm{E}+03$ & 1 & $\begin{array}{r}\text { radioactive- } \\
\text { decay }\end{array}$ & This study \\
\hline U1454 & 354-U1454B-25F-2W, 54-114 cm. & 0.30 & 0.004 & 26,29 & $3.48 \mathrm{E}+04$ & $2.22 \mathrm{E}+03$ & 1 & $\begin{array}{r}\text { radioactive- } \\
\text { decay }\end{array}$ & This study \\
\hline U1454 & 354-U1454B-32F-2W, 80-130 cm. & 1.80 & 0.250 & 21 & $2.98 \mathrm{E}+04$ & $6.47 \mathrm{E}+03$ & 1 & $\begin{array}{r}\text { radioactive- } \\
\text { decay }\end{array}$ & This study \\
\hline $\begin{array}{l}\text { Lower Meghna, } \\
\text { Chor Fasson }\end{array}$ & BGP 34 & 0.00 & - & - & - & - & - & - & \\
\hline $\begin{array}{l}\text { Lower Meghna, } \\
\text { Bhola }\end{array}$ & BR219 & 0.00 & - & - & $3.30 \mathrm{E}+04$ & $2.80 \mathrm{E}+03$ & 1 & - & This study \\
\hline $\begin{array}{l}\text { Lower Meghna, } \\
\text { Bhola }\end{array}$ & BR446 & 0.00 & - & - & $4.94 \mathrm{E}+04$ & $4.65 \mathrm{E}+03$ & 1 & - & This study \\
\hline $\begin{array}{l}\text { Lower Meghna, } \\
\text { Daulatkhan }\end{array}$ & BR8230 & 0.00 & - & - & $3.76 \mathrm{E}+04$ & $6.25 \mathrm{E}+03$ & 1 & - & This study \\
\hline Padma, Mawa & BR529 & 0.00 & - & - & $2.86 \mathrm{E}+04$ & $9098 \mathrm{E}+03$ & 1 & - & This study \\
\hline Padma, Mawa & BR724 & 0.00 & - & - & $4.32 \mathrm{E}+04$ & $3.52 \mathrm{E}+03$ & 1 & - & This study \\
\hline $\begin{array}{l}\text { Ganga, Harding } \\
\text { Bridge }\end{array}$ & Mean & 0.00 & - & - & $2.23 E+04$ & $2.28 \mathrm{E}+03$ & 5 & - & Ref. 28 \\
\hline $\begin{array}{l}\text { Brahmaputra, } \\
\text { Sirajganj/Jamuna } \\
\text { Bridge }\end{array}$ & Mean & 0.00 & - & - & $3.44 E+04$ & $8.09 \mathrm{E}+03$ & 7 & - & Ref. 29 \\
\hline
\end{tabular}




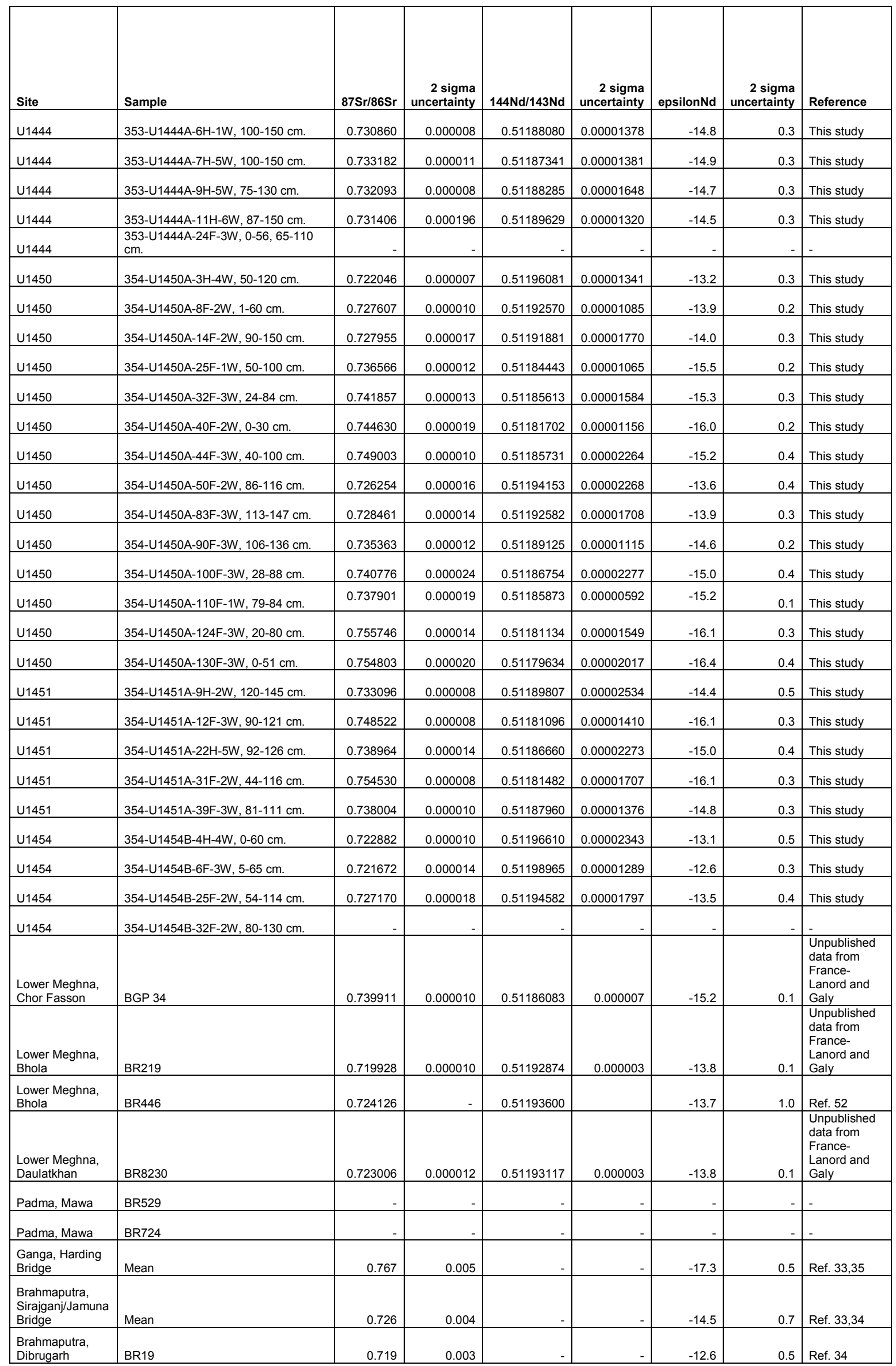




\begin{tabular}{|c|c|c|c|c|}
\hline Site & Sample & $\begin{array}{r}\text { Relative } \\
\text { fraction } \mathrm{f}_{\mathrm{G}}\end{array}$ & $\begin{array}{l}1 \text { sigma } \\
\text { uncertainty }\end{array}$ & Reference \\
\hline U1444 & 353-U1444A-6H-1W, $100-150 \mathrm{~cm}$. & 0.11 & 0.20 & This study \\
\hline U1444 & 353-U1444A-7H-5W, $100-150 \mathrm{~cm}$. & 0.20 & 0.19 & This study \\
\hline U1444 & 353-U1444A-9H-5W, 75-130 cm. & 0.14 & 0.20 & This study \\
\hline U1444 & 353-U1444A-11H-6W, 87-150 cm. & 0.10 & 0.20 & This study \\
\hline U1444 & $\begin{array}{l}\text { 353-U1444A-24F-3W, 0-56, 65-110 } \\
\mathrm{cm} .\end{array}$ & 0.65 & 0.29 & This study \\
\hline U1450 & 354-U1450A-3H-4W, 50-120 cm. & -0.34 & 0.26 & This study \\
\hline U1450 & 354-U1450A-8F-2W, 1-60 cm. & -0.10 & 0.24 & This study \\
\hline U1450 & 354-U1450A-14F-2W, 90-150 cm. & -0.06 & 0.23 & This study \\
\hline U1450 & 354-U1450A-25F-1W, 50-100 cm. & 0.34 & 0.16 & This study \\
\hline U1450 & 354-U1450A-32F-3W, 24-84 cm. & 0.44 & 0.15 & This study \\
\hline U1450 & 354-U1450A-40F-2W, 0-30 cm. & 0.56 & 0.13 & This study \\
\hline U1450 & 354-U1450A-44F-3W, 40-100 cm. & 0.59 & 0.13 & This study \\
\hline U1450 & 354-U1450A-50F-2W, $86-116 \mathrm{~cm}$. & -0.17 & 0.24 & This study \\
\hline U1450 & 354-U1450A-83F-3W, $113-147 \mathrm{~cm}$. & -0.07 & 0.24 & This study \\
\hline U1450 & 354-U1450A-90F-3W, $106-136 \mathrm{~cm}$. & 0.20 & 0.18 & This study \\
\hline U1450 & 354-U1450A-100F-3W, $28-88 \mathrm{~cm}$. & 0.39 & 0.15 & This study \\
\hline U1450 & 354-U1450A-110F-1W, $79-84 \mathrm{~cm}$. & 0.35 & 0.16 & This study \\
\hline U1450 & 354-U1450A-124F-3W, $20-80 \mathrm{~cm}$. & 0.78 & 0.10 & This study \\
\hline U1450 & 354-U1450A-130F-3W, 0-51 cm. & 0.77 & 0.10 & This study \\
\hline U1451 & 354-U1451A-9H-2W, $120-145 \mathrm{~cm}$. & 0.14 & 0.20 & This study \\
\hline U1451 & 354-U1451A-12F-3W, 90-121 cm. & 0.64 & 0.12 & This study \\
\hline U1451 & 354-U1451A-22H-5W, 92-126 cm. & 0.36 & 0.16 & This study \\
\hline U1451 & 354-U1451A-31F-2W, $44-116 \mathrm{~cm}$. & 0.75 & 0.11 & This study \\
\hline U1451 & 354-U1451A-39F-3W, 81-111 cm. & 0.30 & 0.17 & This study \\
\hline U1454 & 354-U1454B-4H-4W, 0-60 cm. & -0.33 & 0.26 & This study \\
\hline U1454 & 354-U1454B-6F-3W, 5-65 cm. & -0.42 & 0.25 & This study \\
\hline U1454 & 354-U1454B-25F-2W, $54-114 \mathrm{~cm}$. & -0.16 & 0.24 & This study \\
\hline U1454 & 354-U1454B-32F-2W, $80-130 \mathrm{~cm}$. & 0.30 & 0.34 & This study \\
\hline Lower Meghna, Chor Fasson & BGP 34 & - & - & - \\
\hline Lower Meghna, Bhola & BR219 & -0.31 & 0.26 & This study \\
\hline Lower Meghna, Bhola & BR446 & -0.22 & 0.25 & This study \\
\hline Lower Meghna, Daulatkhan & BR8230 & -0.07 & 0.24 & This study \\
\hline Padma, Mawa & BR529 & 0.38 & 0.32 & This study \\
\hline Padma, Mawa & BR724 & 0.25 & 0.35 & This study \\
\hline Ganga, Harding Bridge & Mean & 1 & - & - \\
\hline Brahmaputra, Sirajganj/Jamuna Bridge & Mean & 0 & - & - \\
\hline
\end{tabular}




\begin{tabular}{|c|c|c|c|c|}
\hline Site & Sample & $\begin{array}{l}\text { Himalayan } \\
\text { erosion rate } \\
(\mathrm{mm} / \mathrm{y})\end{array}$ & 1 sigma uncertainty $(\mathrm{mm} / \mathrm{y})$ & Reference \\
\hline U1444 & 353-U1444A-6H-1W, $100-150 \mathrm{~cm}$. & 1.1 & 0.1 & This study \\
\hline U1444 & 353-U1444A-7H-5W, 100-150 cm. & 0.8 & 0.1 & This study \\
\hline U1444 & $353-\mathrm{U} 1444 \mathrm{~A}-9 \mathrm{H}-5 \mathrm{~W}, 75-130 \mathrm{~cm}$. & 0.9 & 0.2 & This study \\
\hline U1444 & $353-\mathrm{U} 1444 \mathrm{~A}-11 \mathrm{H}-6 \mathrm{~W}, 87-150 \mathrm{~cm}$. & 1.0 & 0.1 & This study \\
\hline U1444 & $\begin{array}{l}\text { 353-U1444A-24F-3W, 0-56, 65-110 } \\
\mathrm{cm} .\end{array}$ & 0.9 & 0.3 & This study \\
\hline U1450 & $354-U 1450 \mathrm{~A}-3 \mathrm{H}-4 \mathrm{~W}, 50-120 \mathrm{~cm}$. & 1.4 & 0.2 & This study \\
\hline U1450 & $354-\mathrm{U} 1450 \mathrm{~A}-8 \mathrm{~F}-2 \mathrm{~W}, 1-60 \mathrm{~cm}$. & 1.1 & 0.1 & This study \\
\hline U1450 & $354-U 1450 \mathrm{~A}-14 \mathrm{~F}-2 \mathrm{~W}, 90-150 \mathrm{~cm}$. & 1.1 & 0.1 & This study \\
\hline U1450 & 354-U1450A-25F-1W, $50-100 \mathrm{~cm}$. & 1.5 & 0.3 & This study \\
\hline U1450 & $354-U 1450 A-32 F-3 W, 24-84 \mathrm{~cm}$. & 1.2 & 0.3 & This study \\
\hline U1450 & 354-U1450A-40F-2W, 0-30 cm. & 1.1 & 0.2 & This study \\
\hline U1450 & $354-U 1450 \mathrm{~A}-44 \mathrm{~F}-3 \mathrm{~W}, 40-100 \mathrm{~cm}$. & - & - & - \\
\hline U1450 & 354-U1450A-50F-2W, 86-116 cm. & 1.5 & 0.9 & This study \\
\hline U1450 & 354-U1450A-83F-3W, $113-147 \mathrm{~cm}$. & 0.6 & 0.3 & This study \\
\hline U1450 & 354-U1450A-90F-3W, $106-136 \mathrm{~cm}$. & 0.5 & 0.1 & This study \\
\hline U1450 & 354-U1450A-100F-3W, $28-88 \mathrm{~cm}$. & 2.0 & 1.0 & This study \\
\hline U1450 & 354-U1450A-110F-1W, 79-84 cm. & 0.6 & 0.4 & This study \\
\hline U1450 & $354-U 1450 \mathrm{~A}-124 \mathrm{~F}-3 \mathrm{~W}, 20-80 \mathrm{~cm}$. & 0.8 & 0.8 & This study \\
\hline U1450 & $354-U 1450 \mathrm{~A}-130 \mathrm{~F}-3 \mathrm{~W}, 0-51 \mathrm{~cm}$. & - & - & - \\
\hline U1451 & $354-U 1451 \mathrm{~A}-9 \mathrm{H}-2 \mathrm{~W}, 120-145 \mathrm{~cm}$. & 1.0 & 0.2 & This study \\
\hline U1451 & $354-U 1451 \mathrm{~A}-12 \mathrm{~F}-3 \mathrm{~W}, 90-121 \mathrm{~cm}$. & 0.9 & 0.2 & This study \\
\hline U1451 & 354-U1451A-22H-5W, 92-126 cm. & 2.9 & 1.8 & This study \\
\hline U1451 & 354-U1451A-31F-2W, 44-116 cm. & 0.8 & 0.6 & This study \\
\hline U1451 & 354-U1451A-39F-3W, 81-111 cm. & - & - & - \\
\hline U1454 & 354-U1454B-4H-4W, 0-60 cm. & 0.9 & 0.1 & This study \\
\hline U1454 & 354-U1454B-6F-3W, 5-65 cm. & 1.0 & 0.1 & This study \\
\hline U1454 & 354-U1454B-25F-2W, 54-114 cm. & 0.9 & 0.1 & This study \\
\hline U1454 & $354-U 1454 \mathrm{~B}-32 \mathrm{~F}-2 \mathrm{~W}, 80-130 \mathrm{~cm}$. & 1.0 & 0.3 & This study \\
\hline Lower Meghna, Chor Fasson & BGP 34 & - & - & - \\
\hline Lower Meghna, Bhola & BR219 & 0.9 & 0.1 & This study \\
\hline Lower Meghna, Bhola & BR446 & 0.6 & 0.1 & This study \\
\hline Lower Meghna, Daulatkhan & BR8230 & 0.8 & 0.2 & This study \\
\hline Padma, Mawa & BR529 & 1.0 & 0.1 & This study \\
\hline Padma, Mawa & BR724 & 0.7 & 0.1 & This study \\
\hline Ganga, Harding Bridge & Mean & 1.1 & 0.2 & $\begin{array}{l}\text { This study, } \\
\text { recalculated } \\
\text { from data of } \\
\text { Ref. } 30\end{array}$ \\
\hline $\begin{array}{l}\text { Brahmaputra, Sirajganj/Jamuna } \\
\text { Bridge }\end{array}$ & Mean & 0.9 & 0.2 & $\begin{array}{l}\text { This study, } \\
\text { recalculated } \\
\text { from data of } \\
\text { Ref. } 31\end{array}$ \\
\hline
\end{tabular}


Source data for Extended data Fig. 1

\begin{tabular}{|c|c|c|c|c|}
\hline Site & Sample & $\begin{array}{l}{ }^{10} \mathrm{Be} \\
\text { concentration } \\
\text { (atom/g) }\end{array}$ & $\begin{array}{l}1 \text { sigma } \\
\text { uncertainty } \\
\text { (atom/g) } \\
\end{array}$ & Reference \\
\hline U1444 & 353-U1444A-6H-1W, $100-150 \mathrm{~cm}$. & $2.53 \mathrm{E}+04$ & $2.96 \mathrm{E}+03$ & This study \\
\hline U1444 & $353-U 1444 \mathrm{~A}-7 \mathrm{H}-5 \mathrm{~W}, 100-150 \mathrm{~cm}$. & $3.19 \mathrm{E}+04$ & $3.26 \mathrm{E}+03$ & This study \\
\hline U1444 & $353-U 1444 \mathrm{~A}-9 \mathrm{H}-5 \mathrm{~W}, 75-130 \mathrm{~cm}$. & $2.86 \mathrm{E}+04$ & $4.44 \mathrm{E}+03$ & This study \\
\hline U1444 & 353-U1444A-11H-6W, $87-150 \mathrm{~cm}$. & $2.66 \mathrm{E}+04$ & $3.24 \mathrm{E}+03$ & This study \\
\hline U1444 & $\begin{array}{l}\text { 353-U1444A-24F-3W, 0-56, 65-110 } \\
\mathrm{cm} .\end{array}$ & 4.37E+03 & $1.01 \mathrm{E}+03$ & This study \\
\hline U1450 & $354-\mathrm{U} 1450 \mathrm{~A}-3 \mathrm{H}-4 \mathrm{~W}, 50-120 \mathrm{~cm}$. & $1.97 \mathrm{E}+04$ & $2.86 \mathrm{E}+03$ & This study \\
\hline U1450 & 354-U1450A-8F-2W, 1-60 cm. & $2.33 \mathrm{E}+04$ & $2.57 \mathrm{E}+03$ & This study \\
\hline U1450 & 354-U1450A-14F-2W, $90-150 \mathrm{~cm}$. & $2.45 \mathrm{E}+04$ & $1.95 \mathrm{E}+03$ & This study \\
\hline U1450 & 354-U1450A-25F-1W, 50-100 cm. & $1.44 \mathrm{E}+04$ & $2.13 \mathrm{E}+03$ & This study \\
\hline U1450 & $354-U 1450 A-32 F-3 W, 24-84 \mathrm{~cm}$. & $1.62 \mathrm{E}+04$ & $3.09 \mathrm{E}+03$ & This study \\
\hline U1450 & $354-U 1450 \mathrm{~A}-40 \mathrm{~F}-2 \mathrm{~W}, 0-30 \mathrm{~cm}$. & 1.14E+04 & $1.25 \mathrm{E}+03$ & This study \\
\hline U1450 & 354-U1450A-44F-3W, 40-100 cm. & - & - & - \\
\hline U1450 & 354-U1450A-50F-2W, $86-116 \mathrm{~cm}$. & $9.01 \mathrm{E}+03$ & $2.69 \mathrm{E}+03$ & This study \\
\hline U1450 & $354-U 1450 A-83 F-3 W, 113-147 \mathrm{~cm}$. & $1.01 \mathrm{E}+04$ & $2.38 \mathrm{E}+03$ & This study \\
\hline U1450 & $354-U 1450 A-90 F-3 W, 106-136 \mathrm{~cm}$. & $1.24 \mathrm{E}+04$ & $2.29 \mathrm{E}+03$ & This study \\
\hline U1450 & $354-U 1450 \mathrm{~A}-100 \mathrm{~F}-3 \mathrm{~W}, 28-88 \mathrm{~cm}$. & $2.12 \mathrm{E}+03$ & $5.93 \mathrm{E}+02$ & This study \\
\hline U1450 & $354-U 1450 \mathrm{~A}-110 \mathrm{~F}-1 \mathrm{~W}, 79-84 \mathrm{~cm}$. & $6.30 \mathrm{E}+03$ & $1.60 \mathrm{E}+03$ & This study \\
\hline U1450 & 354-U1450A-124F-3W, $20-80 \mathrm{~cm}$. & $2.10 \mathrm{E}+03$ & 7.17E+02 & This study \\
\hline U1450 & $354-U 1450 \mathrm{~A}-130 \mathrm{~F}-3 \mathrm{~W}, 0-51 \mathrm{~cm}$. & - & - & - \\
\hline U1451 & 354-U1451A-9H-2W, $120-145 \mathrm{~cm}$. & $2.65 \mathrm{E}+04$ & $5.32 \mathrm{E}+03$ & This study \\
\hline U1451 & $354-U 1451 \mathrm{~A}-12 \mathrm{~F}-3 \mathrm{~W}, 90-121 \mathrm{~cm}$. & $2.15 \mathrm{E}+04$ & $3.81 \mathrm{E}+03$ & This study \\
\hline U1451 & $354-U 1451 \mathrm{~A}-22 \mathrm{H}-5 \mathrm{~W}, 92-126 \mathrm{~cm}$. & $3.49 \mathrm{E}+03$ & $1.26 \mathrm{E}+03$ & This study \\
\hline U1451 & 354-U1451A-31F-2W, $44-116 \mathrm{~cm}$. & $1.40 \mathrm{E}+03$ & $4.24 \mathrm{E}+02$ & This study \\
\hline U1451 & 354-U1451A-39F-3W, $81-111 \mathrm{~cm}$. & - & - & - \\
\hline U1454 & 354-U1454B-4H-4W, 0-60 cm. & $3.37 \mathrm{E}+04$ & $2.73 \mathrm{E}+03$ & This study \\
\hline U1454 & 354-U1454B-6F-3W, 5-65 cm. & $3.04 \mathrm{E}+04$ & $2.20 \mathrm{E}+03$ & This study \\
\hline U1454 & 354-U1454B-25F-2W, 54-114 cm. & $2.98 \mathrm{E}+04$ & $1.87 \mathrm{E}+03$ & This study \\
\hline U1454 & 354-U1454B-32F-2W, $80-130 \mathrm{~cm}$. & $1.18 \mathrm{E}+04$ & $2.10 \mathrm{E}+03$ & This study \\
\hline Lower Meghna, Chor Fasson & BGP 34 & - & - & - \\
\hline Lower Meghna, Bhola & BR219 & $3.30 \mathrm{E}+04$ & $2.80 \mathrm{E}+03$ & This study \\
\hline Lower Meghna, Bhola & BR446 & $4.94 \mathrm{E}+04$ & $4.65 \mathrm{E}+03$ & This study \\
\hline Lower Meghna, Daulatkhan & BR8230 & $3.76 \mathrm{E}+04$ & $6.25 \mathrm{E}+03$ & This study \\
\hline Padma, Mawa & BR529 & $2.86 \mathrm{E}+04$ & $2.98 \mathrm{E}+03$ & This study \\
\hline Padma, Mawa & BR724 & $4.32 E+04$ & $3.52 \mathrm{E}+03$ & This study \\
\hline
\end{tabular}


Source data for Extended data Fig. 7

\begin{tabular}{|c|c|c|c|c|}
\hline Site & Sample & $\begin{array}{l}\begin{array}{l}\text { Fraction } \\
\text { (microns) }\end{array} \\
\end{array}$ & $\begin{array}{l}{ }^{10} \mathrm{Be} \\
\text { concentration } \\
\text { (atom/g) }\end{array}$ & $\begin{array}{l}1 \text { sigma } \\
\text { uncertainty } \\
\text { (atom/g) } \\
\end{array}$ \\
\hline U1444 & 353-U1444A-6H-1W, $100-150 \mathrm{~cm}$. & $125-250$ & $2.53 \mathrm{E}+04$ & $2.96 \mathrm{E}+03$ \\
\hline U1444 & 353-U1444A-7H-5W, $100-150 \mathrm{~cm}$. & $125-250$ & $3.19 \mathrm{E}+04$ & $3.26 \mathrm{E}+03$ \\
\hline U1450 & $354-U 1450 \mathrm{~A}-3 \mathrm{H}-4 \mathrm{~W}, 50-120 \mathrm{~cm}$. & $125-250$ & 1.97E+04 & $2.86 \mathrm{E}+03$ \\
\hline U1450 & 354-U1450A-8F-2W, 1-60 cm. & $125-250$ & $2.33 E+04$ & $2.57 \mathrm{E}+03$ \\
\hline U1450 & 354-U1450A-25F-1W, 50-100 cm. & $125-250$ & $1.44 \mathrm{E}+04$ & $2.13 \mathrm{E}+03$ \\
\hline Padma, Mawa & BR529 & $125-250$ & $3.25 \mathrm{E}+04$ & $2.95 \mathrm{E}+03$ \\
\hline U1444 & $353-\mathrm{U} 1444 \mathrm{~A}-6 \mathrm{H}-1 \mathrm{~W}, 100-150 \mathrm{~cm}$. & $75-250$ & $2.07 \mathrm{E}+04$ & $3.28 \mathrm{E}+03$ \\
\hline U1444 & 353-U1444A-7H-5W, $100-150 \mathrm{~cm}$. & $75-125$ & $2.23 E+04$ & $3.83 \mathrm{E}+03$ \\
\hline U1450 & 354-U1450A-3H-4W, 50-120 cm. & $75-125$ & $2.13 E+04$ & $4.71 \mathrm{E}+03$ \\
\hline U1450 & 354-U1450A-8F-2W, 1-60 cm. & $75-250$ & $2.53 \mathrm{E}+04$ & $4.08 \mathrm{E}+03$ \\
\hline U1450 & 354-U1450A-25F-1W, 50-100 cm. & $75-250$ & $1.11 \mathrm{E}+04$ & $4.05 E+03$ \\
\hline Padma, Mawa & BR529 & $75-125$ & $3.25 \mathrm{E}+04$ & $2.95 E+03$ \\
\hline
\end{tabular}




\section{Supplementary Information for}

\section{Steady erosion rates in the Himalayas through late Cenozoic climatic changes}

Sebastien J.P. Lenard*, Jérôme Lavé, Christian France-Lanord, Georges Aumaître, Didier L. Bourlès, Karim Keddadouche

The Supplementary Information develops the interpretation of the Sr-Nd isotopic variations and of the Ganga fraction $f_{G}$.

\section{Interpretation of the Sr-Nd isotopic variations}

The sediment of the Bengal Fan and the Lower Meghna River should reflect a mixing between Ganga and Brahmaputra sediments, which derive from a mix of Himalayan formations. From south to north, these formations consist in Himalayan formations s.s., the Lesser Himalaya, the High Himalaya Crystalline and the Tethyan Sedimentary Series, and in Transhimalayan formations. These formations have distinct $\mathrm{Sr}-\mathrm{Nd}$ isotopic signatures, as shown by ref. ${ }^{32}$ in their Fig. 10.

Because the Ganga and Brahmaputra Rivers and their tributaries drain distinct formations, their sediment have a distinct isotopic Sr-Nd signature (Fig. 2c) ${ }^{33-35,68}$. The Ganga signature is dominated by Himalayan tributaries, which drain the Himalayan formations s.s. The signature of the Brahmaputra at Dibrugarh (BD location in Fig. 1), close to the range outlet, is enriched in Transhimalayan and mantle-derived formations drained by the YarlungTsangpo River in Tibet and by eastern tributaries. The signature of the Brahmaputra at Jamuna Bridge (B location in Fig. 1), close to the delta, results from a dilution of the signature by Himalayan tributaries that only drain Himalayan s.s. formations and that have a signature similar to the signature of the Ganga.

The sediment of the Lower Meghna River and of the Bengal Fan is presumed to follow a mixing trend between two poles, the Ganga and the Brahmaputra Rivers. As shown by results from the late Cenozoic foreland sediment in Central Himalaya ${ }^{61-63}$, the Himalayan tributaries and therefore the Ganga River are assumed to have had a past signature roughly close to the modern one since ca. $10 \mathrm{Ma}$. The past signature of the Brahmaputra is enriched in Transhimalayan formations and has been close to the signature of the Brahmaputra at 
Dibrugarh since ca. $7 \mathrm{Ma}$, according to results from the late Cenozoic foreland sediment in Eastern Himalaya ${ }^{64}$ and in the Surma Basin, south of the Shillong Plateau ${ }^{65}$.

\section{Interpretation of the $f_{G}$ values}

The $f_{G}$ values are distributed in a range of 0 to $\sim 80 \%$ and include negative values. The model explaining our results probably evolves between two extreme scenarios. In the first scenario, the signature is explained by a sequestration of coarse sand in the Ganga plain and a contribution of the Brahmaputra in the sedimentary flux higher than the contribution of the Ganga, according to our geochemical and granulometric budgets (Extended Fig. 4). In modern times, such a sequestration in the Ganga plain might be partly attributed to the Farakka Barrage, which controls the river and sedimentary flux of the Ganga to the Bengal Delta. Still, because the dam is let open by the regular management of the Farakka Barrage during the monsoon, from July to October, it does not appear as a dominant sequestration factor.

This scenario can explain all signatures, but in that case, the Brahmaputra signature should have a negligible Himalayan s.s. component and be close to the Brahmaputra at Dibrugarh poles, as suggested by the late Cenozoic foreland record, and not close to the Brahmaputra at Jamuna Bridge, as suggested by the modern record (Fig. 1). Such a signature may reflect extreme events that could lead to direct pulses of sediment from the range outlet to Bangladesh, without minimum dilution by Himalayan s.s. tributaries. Alternatively, this may reflect erosion conditions that favour strongly the erosion of the Transhimalaya compared to the Himalaya s.s.

In the second scenario, the signature is explained by distinct routing systems for Ganga and Brahmaputra sediment ${ }^{18,27,37}$. This scenario could explain the $f_{G}$ in the -20 to $20 \%$ range and the $f_{G}$ close to $80 \%$. 